\begin{abstract}
The Corded Ware culture (CWC) cemetery at site 15 in Święte, Radymno Commune, Jarosław District, was researched in 2010-2011 in the context of rescue excavations before the construction of the A4 motorway. Nine features were discovered, including six graves with a niche construction. An analysis of funerary rite traits and relics forming the grave inventory indicates that the above is linked with the later stage of the CWC development in Lesser Poland. Analogical materials are found in the neighbouring sites 11 and 20 in Święte and 7 in Skołoszów. On the basis of radiocarbon dating the chronology of the cemetery complex was defined to the period 2525-2380 BC. An interesting element of grave inventories is vessels analogous to finds from the Middle Dnieper and Catacomb cultures. These point to the ties of communities using the cemetery complex in Święte with those to the east of Lesser Poland - confirmed in the analysis conducted of stable isotopes of strontium.
\end{abstract}

ABSTRACT

Key words: Final Eneolithic, Corded Ware culture, south-eastern Poland, funeral rite 
Rescue excavation research before the construction of the A4 motorway at site 15 in Święte (AZP 127/106-84), Radymno Commune, Jarosław District, was conducted in the period 2010-2011. The consortium Narnia-Arche-Archgeo was responsible (research heads: Piotr Janczewski and Piotr Brożyna). In sum, an area of 2.78 ha was examined. In such a large area the number of finds dated to prehistoric periods was small and limited itself to 9 features from the Corded Ware culture (CWC) and 10 features of the Trzciniec culture (TC). There were also documented trenches and other features connected with the period of World War I.

The site is located south-west of the village of Święte and its buildings, on the edge of a vast, Pleistocene meadow terrace of the River San, the western part of the valley (Fig. 1). The terrace is over $10 \mathrm{~km}$ wide and its ceiling is created by a loess layer of considerable thickness. There, black earth soils have formed, originally with a $1 \mathrm{~m}$ thick profile. Across the entire area of the site under discussion the black earth humus has been preserved in situ.

In the direction of the contemporary bed of the San valley (about $1 \mathrm{~km}$ east from the site) the terrace falls steeply with an edge 12-15 $\mathrm{m}$ in height [Reder 2013]. From the north the site is limited by an erosive valley up to $7 \mathrm{~m}$ deep, leading to the San valley. The terrace surface around the site is characterised by undulation and



Fig. 1. Location of site 15 in Święte, Radymno Commune, Jarosław District 
the presence of a depression typical of landlocked troughs. At present these forms are levelled out and filled in with soil denudation substances. Only the largest of these are still visible in the terrain topography. The height of the area under discussion measures 203-204 m a.s.l.

The majority of CWC graves was located in the eastern, only partially surveyed, part of the site (Fig. 2). There were three concentrations formed, separated more than $20 \mathrm{~m}$ from one another:

a) features 408 and 409 ,

b) features $405 \mathrm{~A}$ and 407 ,

c) features $423,426,427$ and $431 \mathrm{~A}$.

Beyond this zone, some $100 \mathrm{~m}$ to the west, grave 173 could be found. No other Eneolithic features were found its environs. Only the odd few pits associated with Trzciniec culture settlements were recorded.

Moreover, no traces were preserved that could possibly testify to the existence of tumulus mounds. These possibly could have been secondary features dug into the mound fill, which is not suggested however by the placement of graves among each other (they do not create arches towards the middle of the mound). It should therefore be accepted that the CWC features from site 15 were part of an area of small, flat cemetery complexes on the peaks of hills above the San valley - as in the case of the nearby graves from sites 11 and 20 in Święte [Dobrakowska, Włodarczak 2018; Olszewski, Włodarczak 2018] as well as 7 in Skołoszów [Rybicka et al. 2017]. Part of these constructions (at site 7 in Skołoszów and 11 in Święte) most likely arose by long barrows of the Funnel Beaker culture. Notwithstanding, graves discovered at the sites there were also considerably at a distance - some several dozen metres - from the Middle Eneolithic long barrow.

In all likelihood there were more Final Eneolithic graves at site 15 in Święte, though for reasons as yet unclear however, the entire eastern area of the site, localised within the radius of investment works, has not been surveyed. 


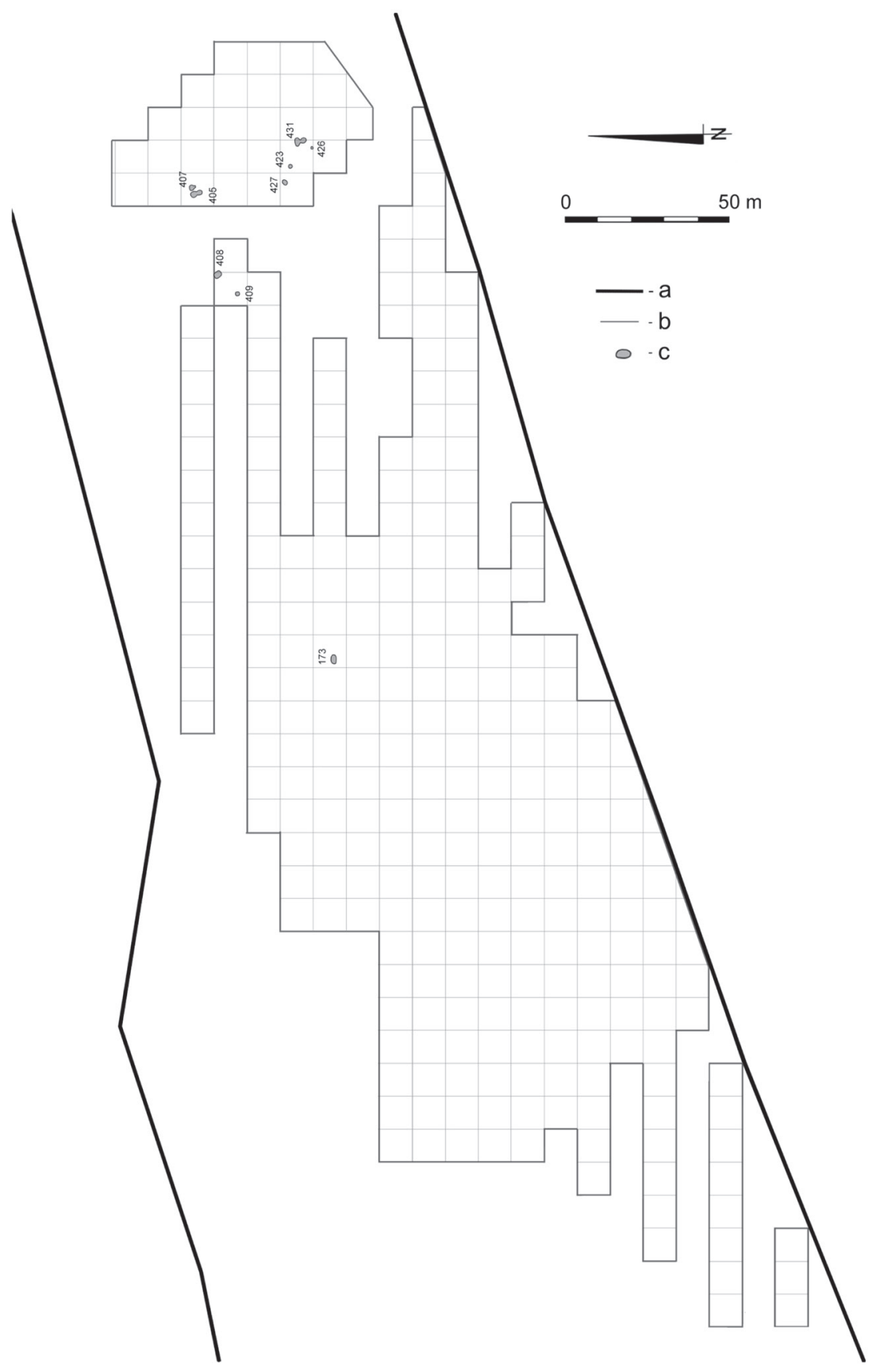

Fig. 2. Święte, site 15. Plan of excavated area with CWC graves marked. a - limit of investition, $\mathrm{b}-$ limit of excavated area, $\mathrm{c}-\mathrm{CWC}$ graves 
1. DESCRIPTION OF GRAVES

\section{Grave $173^{1}$}

\begin{tabular}{|l|l|l|l|}
\hline Chronology & \multicolumn{2}{|l|}{ Poz-90779: 3935 \pm 30 BP 2480-2348 BC } \\
\hline Construction type & \multirow{2}{*}{ Niche? } & Number of burials & 1 \\
\cline { 3 - 4 } & & Sex & Female \\
\cline { 3 - 4 } & & Age & $40-50$ years \\
\hline $\begin{array}{l}\text { Niche grave } \\
\text { dimensions (m) }\end{array}$ & $1.75 \times 1.15$ & Orientation & N-E \\
\hline Depth $(\mathrm{m})$ & 0.5 & Deviation & $0^{\circ}$ \\
\hline Niche orientation & N-S & $\begin{array}{l}\text { Placement of head/ } \\
\text { body/lower limbs }\end{array}$ & L/B/L \\
\cline { 3 - 4 } & & Lower limbs & 2 \\
\cline { 3 - 4 } & & Upper limbs & $\mathrm{I}$ \\
\hline
\end{tabular}

The analysis of documentation points to a niche construction of a grave unidentified during field research. The entrance pit was situated east of the niche. Its corridor led to the niche through a steep, small threshold about $30 \mathrm{~cm}$ in height (Fig. 3: B; 6). The niche was oval in shape, the fill multilayered and composed of dark grey brown earth as well as traces of yellow loess. The deceased was placed in a contracted position, supine, head and lower limbs turned to the left (Fig. 3: C; 5) ${ }^{2}$. Two vessels were discovered by the individual's pelvis. Moreover, at the burial level a flint knife insert was found.

\section{Inventory:}

1. Large bipartite beaker, S-profile. Ornamental in the upper part with six rows of Z-twisted cord imprints. External surface even, mat, light brown. Dimensions: height $-22.7 \mathrm{~cm}$, spout diameter $-13.2 \mathrm{~cm}$, belly diameter $-18.3 \mathrm{~cm}$, bottom diameter $-5.5 \mathrm{~cm}$, wall thickness $-0.6 \mathrm{~cm}$. Fig. $4: 1$.

2. Miniature vessel in the form of a beaker, made without particular care, embellished with uneven, incised vertical lines and vertical incisions. The external surface uneven, light brown. Dimensions: height $-5.5 \mathrm{~cm}$, spout diameter $-4 \mathrm{~cm}$, belly diameter $-4.9 \mathrm{~cm}$, wall thickness $-0.3-0.4 \mathrm{~cm}$. Fig. 4: 2 .

3. Eastern cretaceous flint negative bipolar flake splinter. Retouched flat, irregular, bifacial on the left side. The tool has the form of a small, knife-like back blade insert with traces of having been worked (worn sheen, micro-retouch) on the blade. Dimensions: $33 \times 26 \times 7$ mm. Fig. $4: 3$.

${ }^{1}$ Legend for symbols used in tables:

Placement of head/corpus/lower limbs: $\mathrm{R}$ - right side, $\mathrm{L}$ - left side, $\mathrm{U}$ - supine.

Lower limbs: see Włodarczak 2006: 58. Fig. 31: B and 60. table 13.

Upper limbs: see Włodarczak 2006: 58. Fig. 31: A.

${ }^{2}$ For details of anthropological analysis of burials - see Szczepanek 2018. 

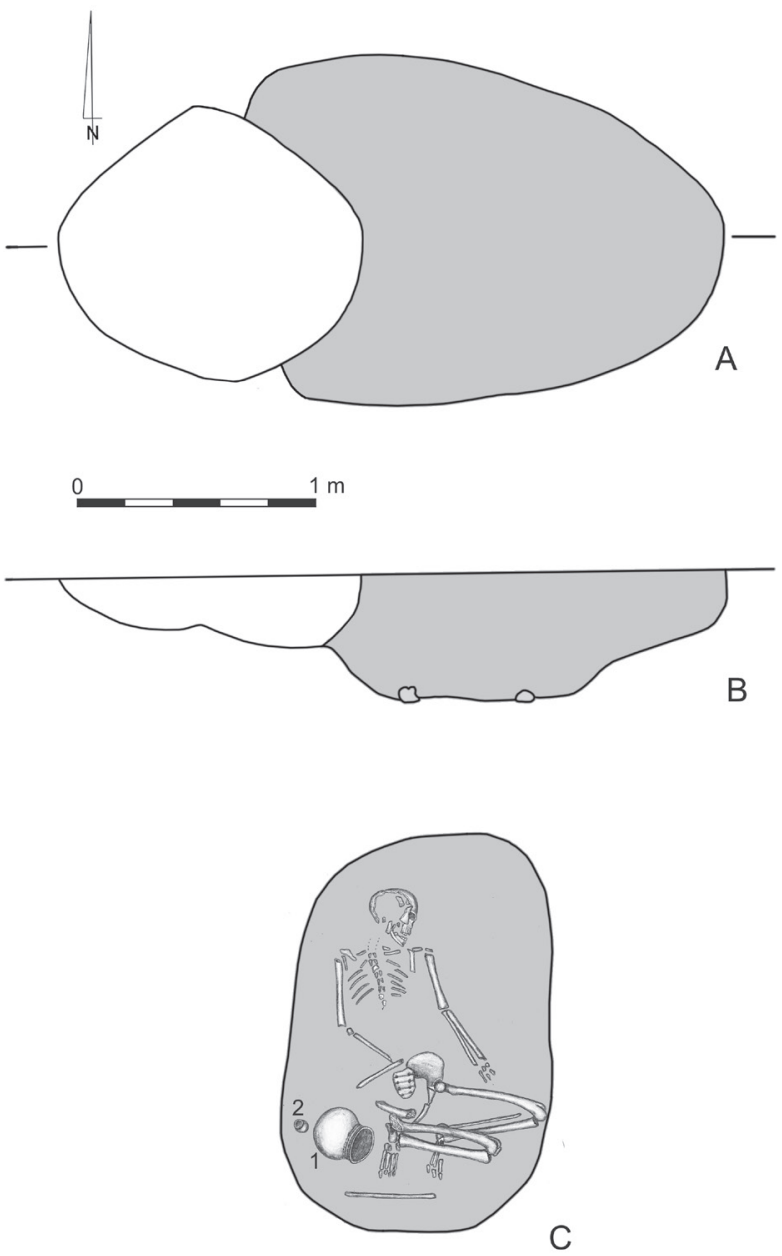

Fig. 3. Święte, site 15. Grave 173: A - plan, discovery level, B - vertical profile, C-burial level. Drawing M. Podsiadło 


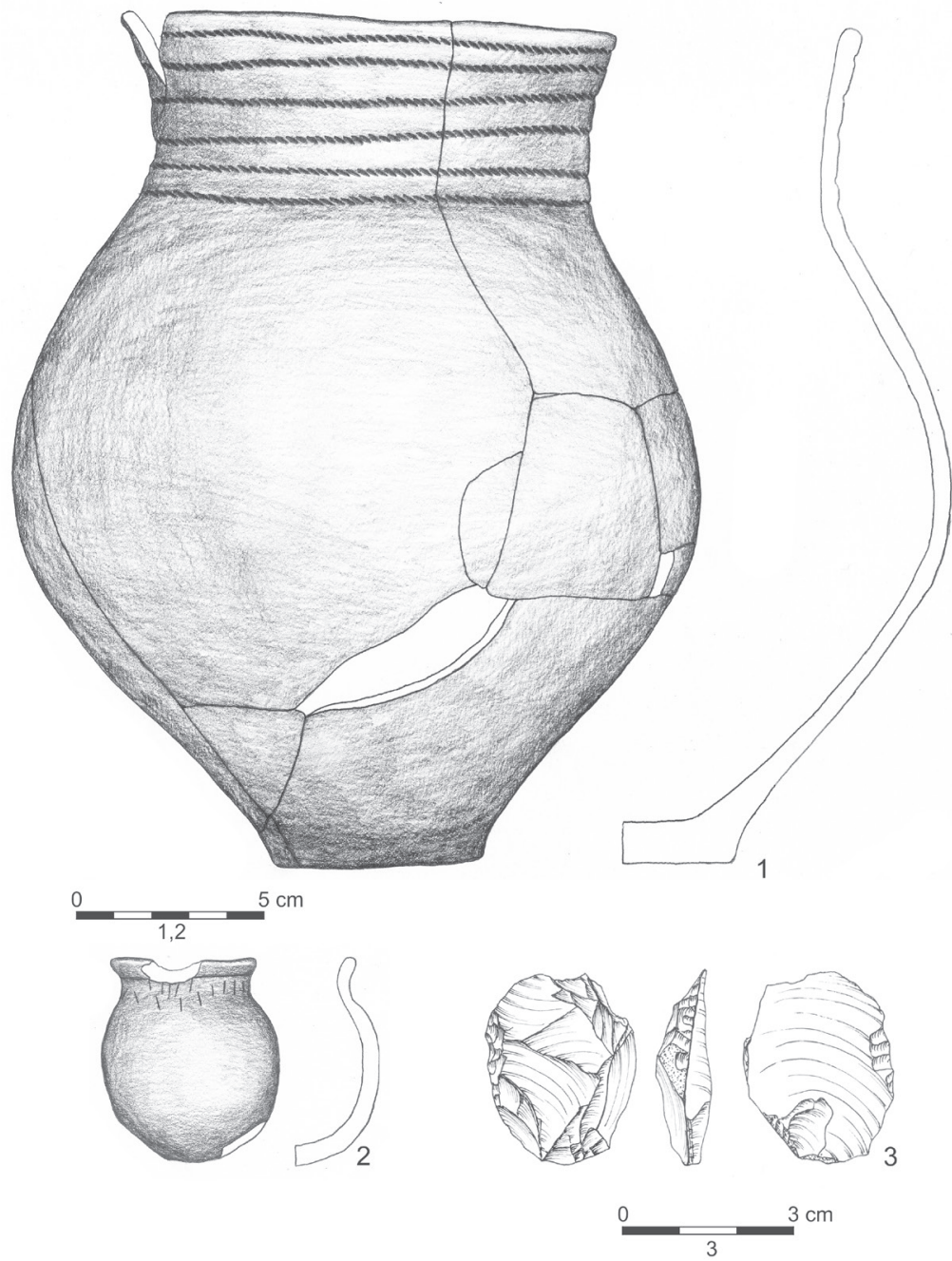

Fig. 4. Święte, site 15. Grave 173: 1-3 - inventory. Drawing A. Dziedzic, M. Podsiadło 


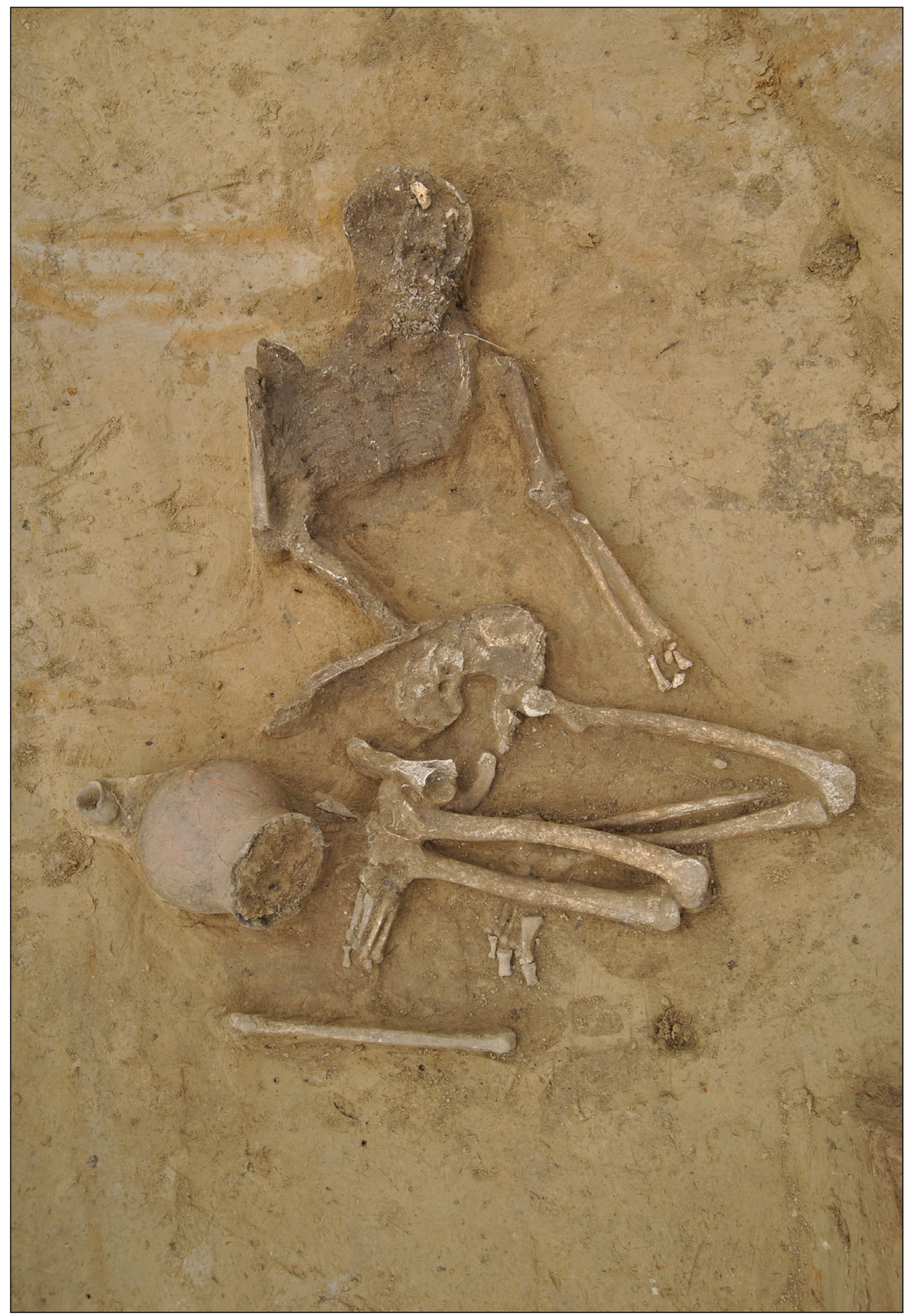

Fig. 5. Święte, site 15. Grave 173: burial level. Photo K. Grenda 


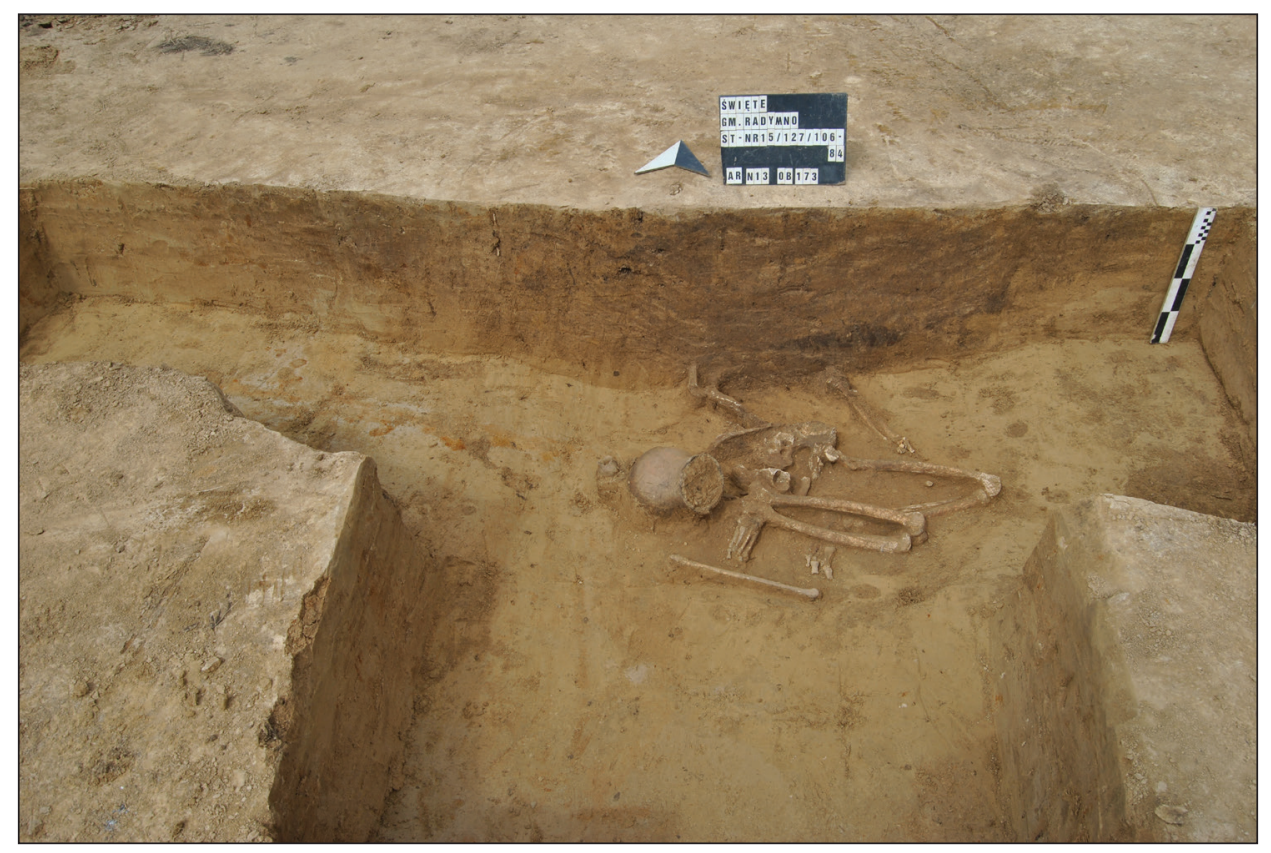

Fig. 6. Święte, site 15. Grave 173: feature profile. Photo K. Grenda

\section{Grave 405A}

\begin{tabular}{|l|l|l|l|}
\hline Chronology & \multicolumn{3}{|l|}{} \\
\hline Construction type & \multirow{2}{*}{ niche } & Number of burials & $1 ?$ \\
\cline { 3 - 4 } & & Sex & $?$ \\
\cline { 3 - 4 } & & Age & $>20$ years \\
\hline $\begin{array}{l}\text { Niche grave } \\
\text { dimensions (m) }\end{array}$ & $1.15 \times 1.0$ & Orientation & $?$ \\
\hline Depth (m) & 0.75 & Deviation & - \\
\hline Niche orientation & W-E & $\begin{array}{l}\text { Placement of head/ } \\
\text { body/lower limbs }\end{array}$ & $?$ \\
\cline { 3 - 4 } & & Lower limbs & $?$ \\
\cline { 3 - 4 } & & Upper limbs & $?$ \\
\hline
\end{tabular}

Well preserved niche construction. Entrance pit (feature 405) oval in horizontal profile (dimensions: $1.15 \times 0.75 \mathrm{~m}$ ) and regular rectangle in vertical profile (Fig. 7: A). Its fill was made up in the main of light grey brown earth (Fig. 13). A layer of dark brown earth was only present at the northern edge of the pit. A regular, straight border between these layers is a clear testimony to the presence of a partition blocking the entrance to the niche (Fig. 12; 13). The corridor leading hori- 


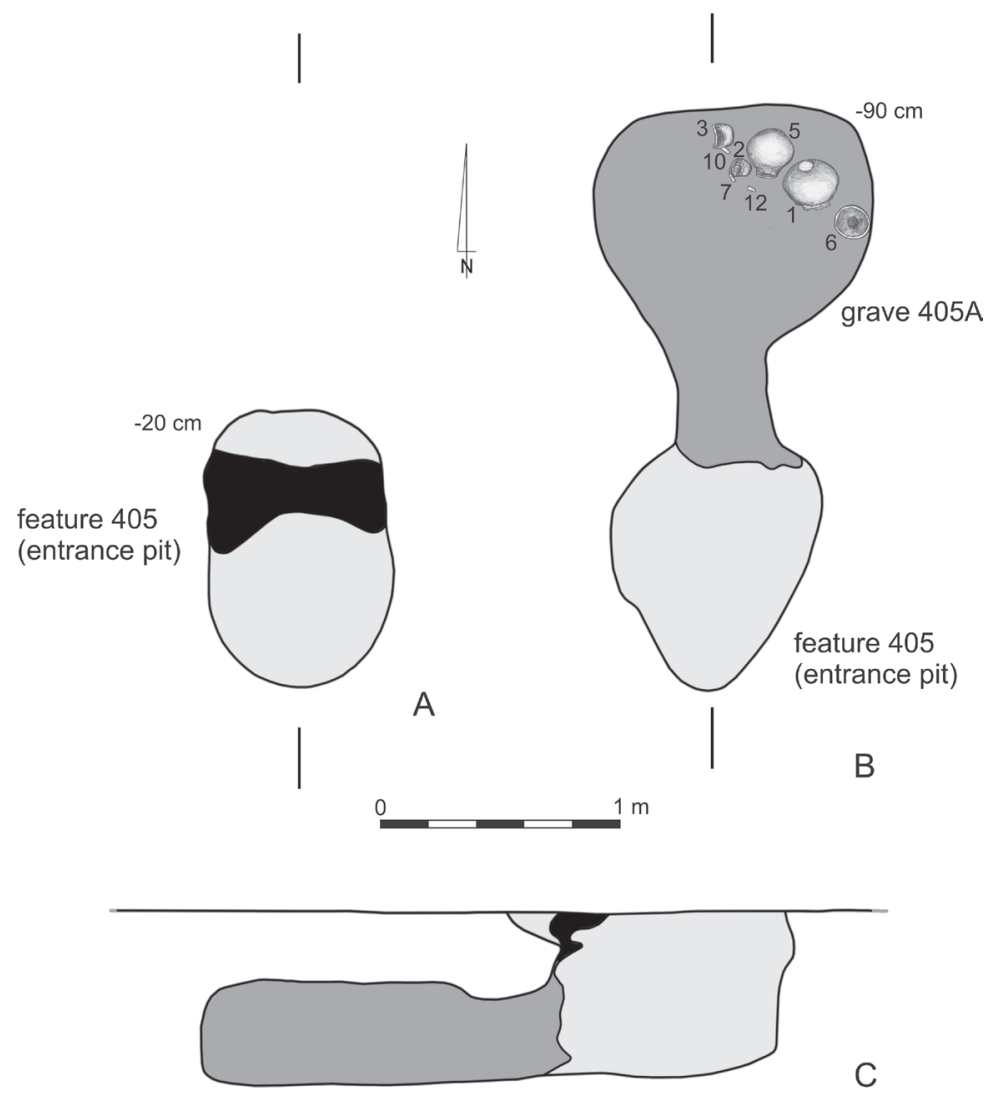

Fig. 7. Święte, site 15. Grave 405A: A - plan, discovery level, B - burial level, C - vertical profile of grave. Drawing M. Podsiadło

zontally to the niche was narrow and about $40 \mathrm{~cm}$ long (Fig. 7: B). The niche was oval and its ceiling was straight, horizontal. At its bottom there was only one poorly preserved human bone as well as furnishings made up of six vessels (Fig. 7: C), seven flint artefacts and stone axe.

Inventory:

1. A slim upper belly two-handle amphora. Embellished with seven rows of Z-twisted thick cord imprints. Dimensions: height $-22.8 \mathrm{~cm}$, spout diameter $11.2 \mathrm{~cm}$, belly diameter $-20.7 \mathrm{~cm}$, bottom diameter $-5.2 \mathrm{~cm}$. Fig. 8: 1 .

2. Small beaker, embellished in the upper part, with a row of likely slanted impressions and two rows of herringbone imprints. Dimensions: height $-6.4 \mathrm{~cm}$, spout diameter $-9.0 \mathrm{~cm}$, bottom diameter $-6.5 \mathrm{~cm}$. Fig. 8: 2 .

3. S-profile beaker, undecorated, with uneven external wall surfaces. Dimensions: height $-11.5 \mathrm{~cm}$, spout diameter $-9.9 \mathrm{~cm}$, belly diameter $-11.2 \mathrm{~cm}$, bottom diameter $-6.0 \mathrm{~cm}$. Fig. 9: 3 . 

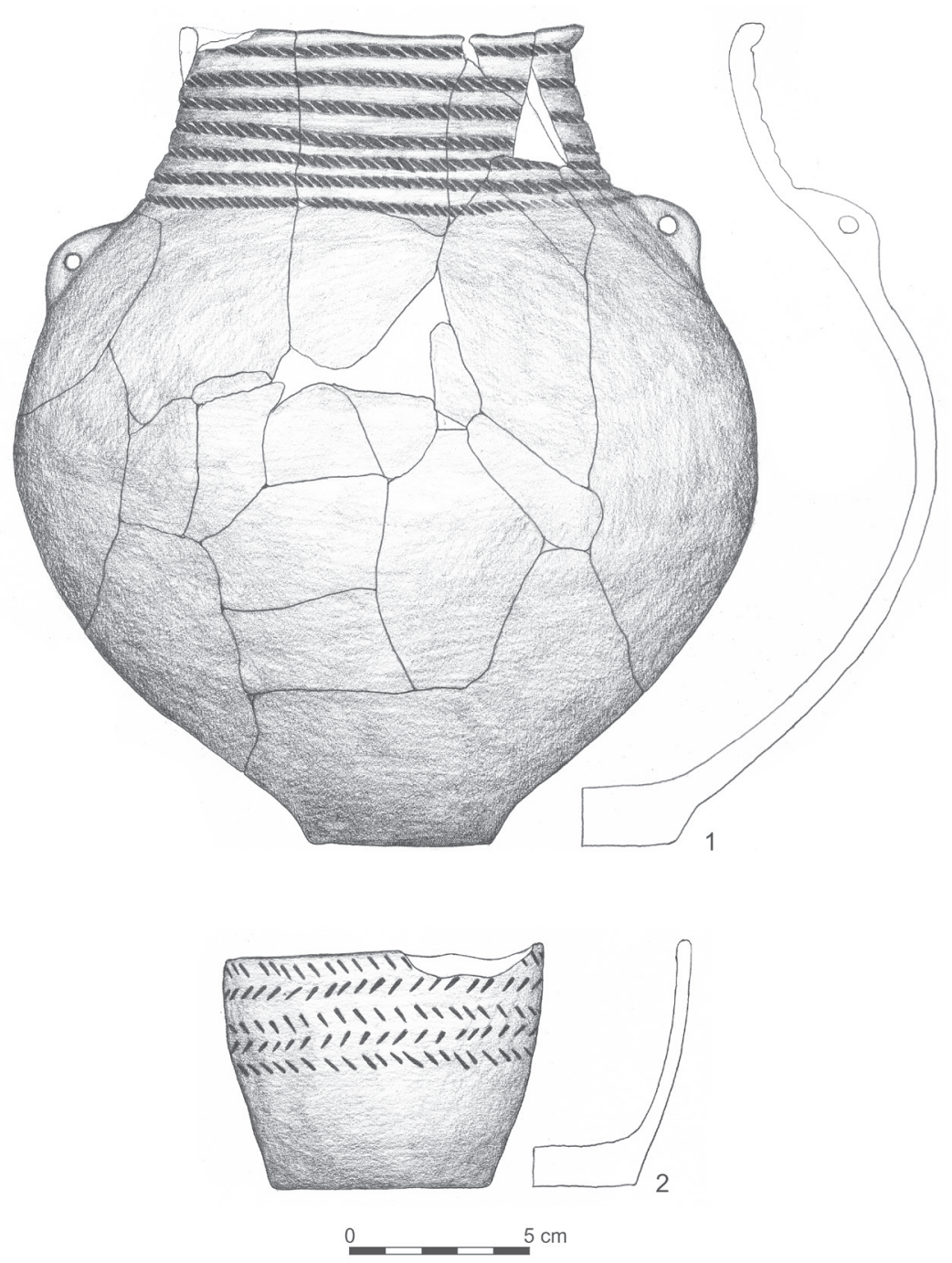

Fig. 8. Święte, site 15. Grave 405A: 1-2 - inventory. Drawing M. Podsiadło

4. Small broad-mouth beaker embellished at the neck as well as the upper belly part with 5-6 rows of uneven, vertical incisions. Dimensions: height - about $14 \mathrm{~cm}$, spout diameter - ca. $11.0 \mathrm{~cm}$, belly diameter $-14.5 \mathrm{~cm}$. Fig. 9: 4 .

5. S-profile beaker, embellished at the spout with 3-4 rows of S-twisted cord imprints. Bottom not outlined, somewhat concave. Dimensions: height $-17.0 \mathrm{~cm}$, spout diameter $-8.2 \mathrm{~cm}$, belly diameter $-17.6 \mathrm{~cm}$, bottom diameter $-7.3 \mathrm{~cm}$. Fig. 10: 5. 

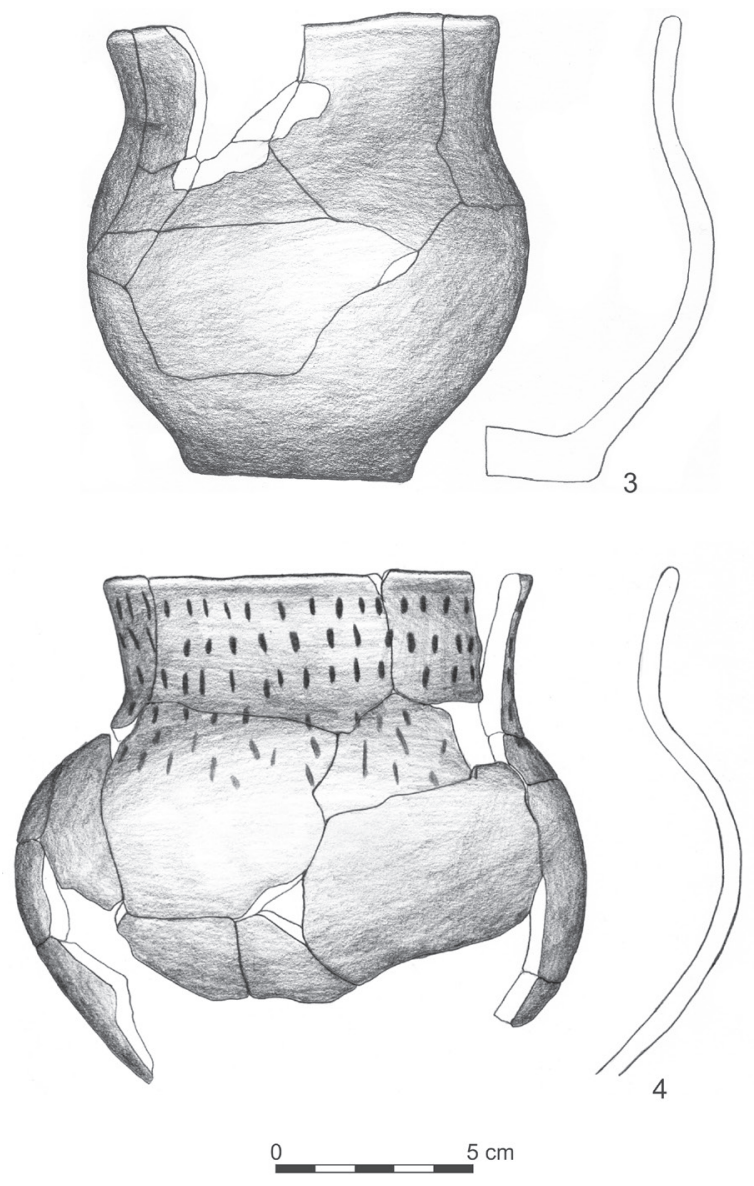

Fi g. 9. Święte, site 15. Grave 405A: 3-4 - inventory. Drawing M. Podsiadło

6. The belly of the vessel (most likely beaker) with a flat, not outlined bottom. On the preserved fragment at the shoulder of the small neck there is present an embellishment in the form of slanted incisions (herringbone), while in the upper part of the small neck there are horizontal imprints of Z-twisted cord. Inside the belly there were traces of carbonized organic deposit. Dimensions: height of the belly $-11.1 \mathrm{~cm}$, belly diameter $-14.2 \mathrm{~cm}$, bottom diameter $-4.9 \mathrm{~cm}$. Fig. 10: 6 .

7. Cretaceous eastern flint flake, with micro-retouch and worn sheen on both edges. At the top a small fragment of a cortical surface. Dimensions: $5.6 \times 2.4 \times$ $0.6 \mathrm{~cm}$. Fig. 11: 7 .

8. Cretaceous eastern negative flint flake, with a small fragment of cortex in the distal part. Dimensions: $4.2 \times 4.5 \times 0.4 \mathrm{~cm}$. Fig. $11: 8$. 

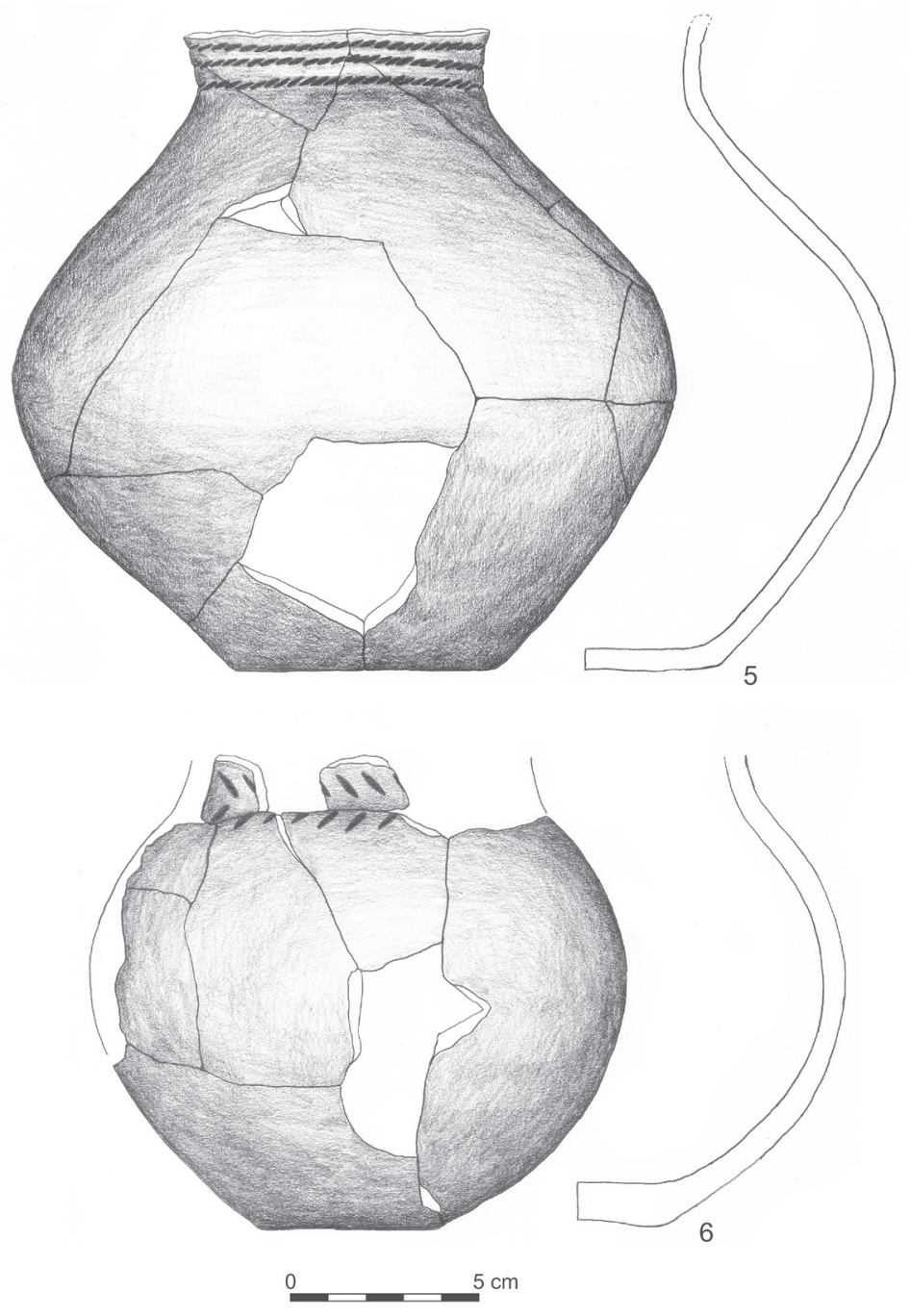

Fig. 10. Święte, site 15. Grave 405A: 5-6 - inventory. Drawing M. Podsiadło

9. The distal part of a partially cortical eastern cretaceous flint flake. Dimensions: $3.0 \times 2.2 \times 0.3 \mathrm{~cm}$. Fig. $11: 9$.

10. A partially cortical cretaceous eastern flake. Dimensions: $3.8 \times 2.5 \times$ 0.4 cm. Fig. 11: 10 .

11. The distal part of a partially cortical eastern cretaceous flint flake. Dimensions: $3.1 \times 1.9 \times 0.4 \mathrm{~cm}$. Fig. $11: 11$.

12. Cortical flake with blade portions ('para-blade'). Dimensions: $4.5 \times 2.2 \times$ $0.5 \mathrm{~mm}$. Fig. 11: 12. 

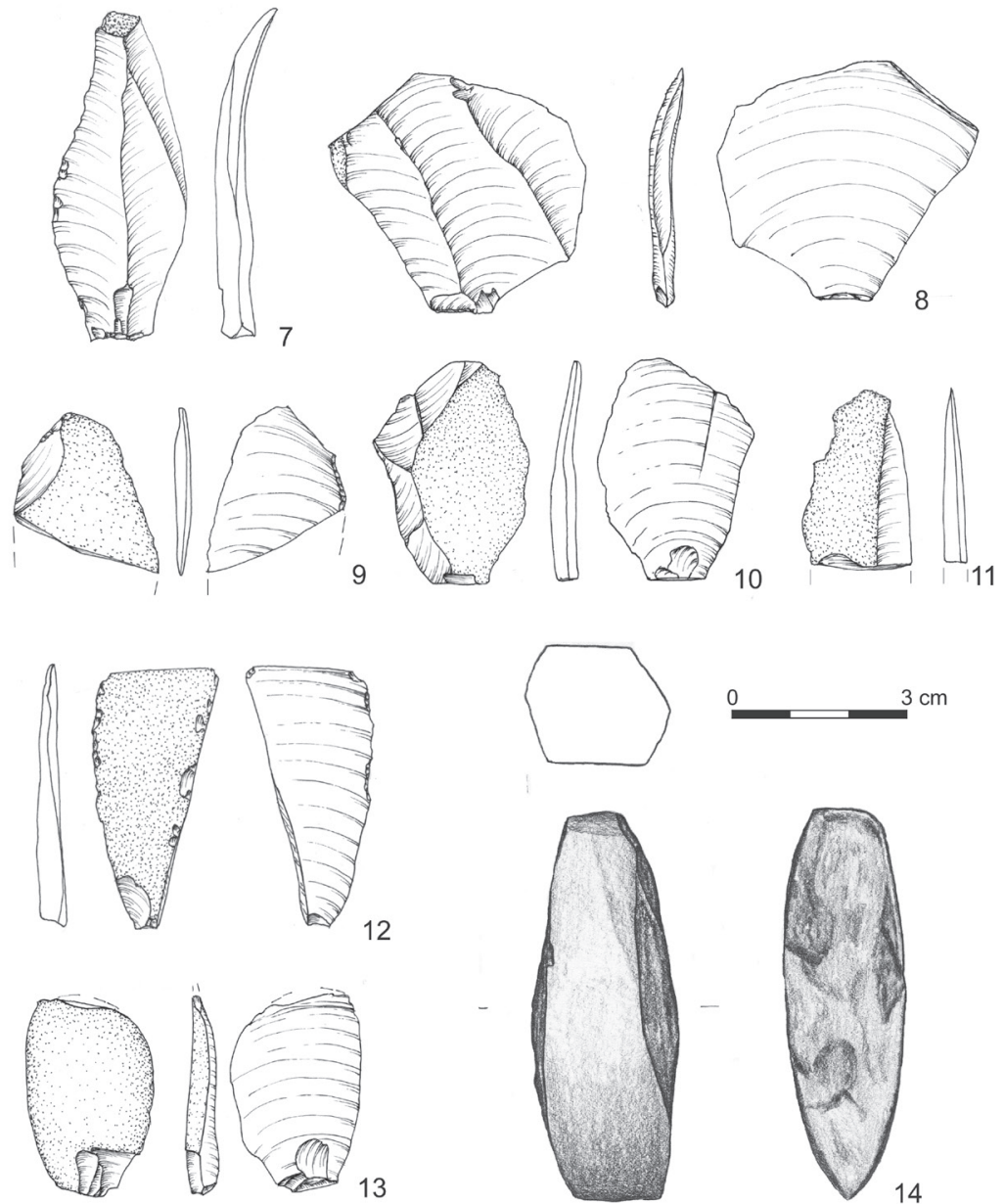

Fig. 11. Święte, site 15. Grave 405A: 7-14 - inventory. Drawing A. Dziedzic, M. Podsiadło

13. Eastern cretaceous cortical flake. Dimensions: $3.2 \times 2.3 \times 0.5 \mathrm{~cm}$. Fig. 11: 13.

14. Rectangular axe of siliceous Carpathian marl. A reworking of a larger tool that arose through the re-forming of both sides. Both surfaces in the main smoothed. Blade somewhat asymmetrical. Tetrahedral butt, not tapered. Dimensions: length $6.7 \mathrm{~cm}$, blade width $-1.7 \mathrm{~cm}$, butt width $-0.7 \mathrm{~cm}$, thickness $-2.1 \mathrm{~cm}$. Fig. 11: 14 . 


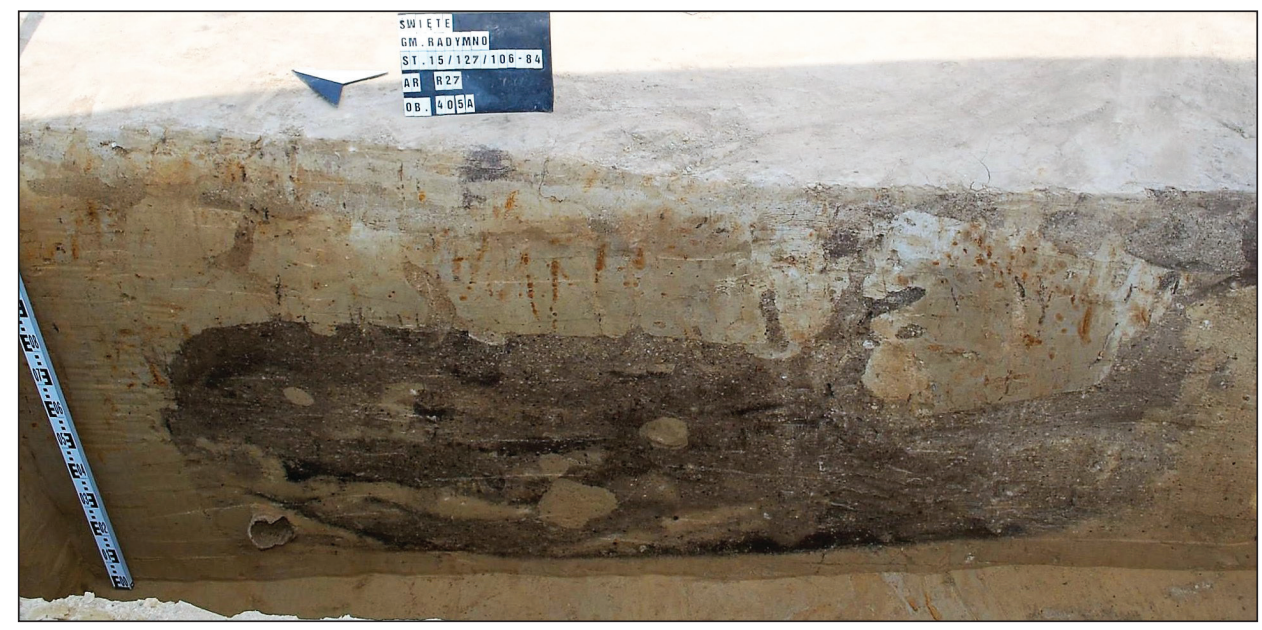

Fig. 12. Święte, site 15. Grave 405A: vertical profile of niche. Photo M. Mądzik

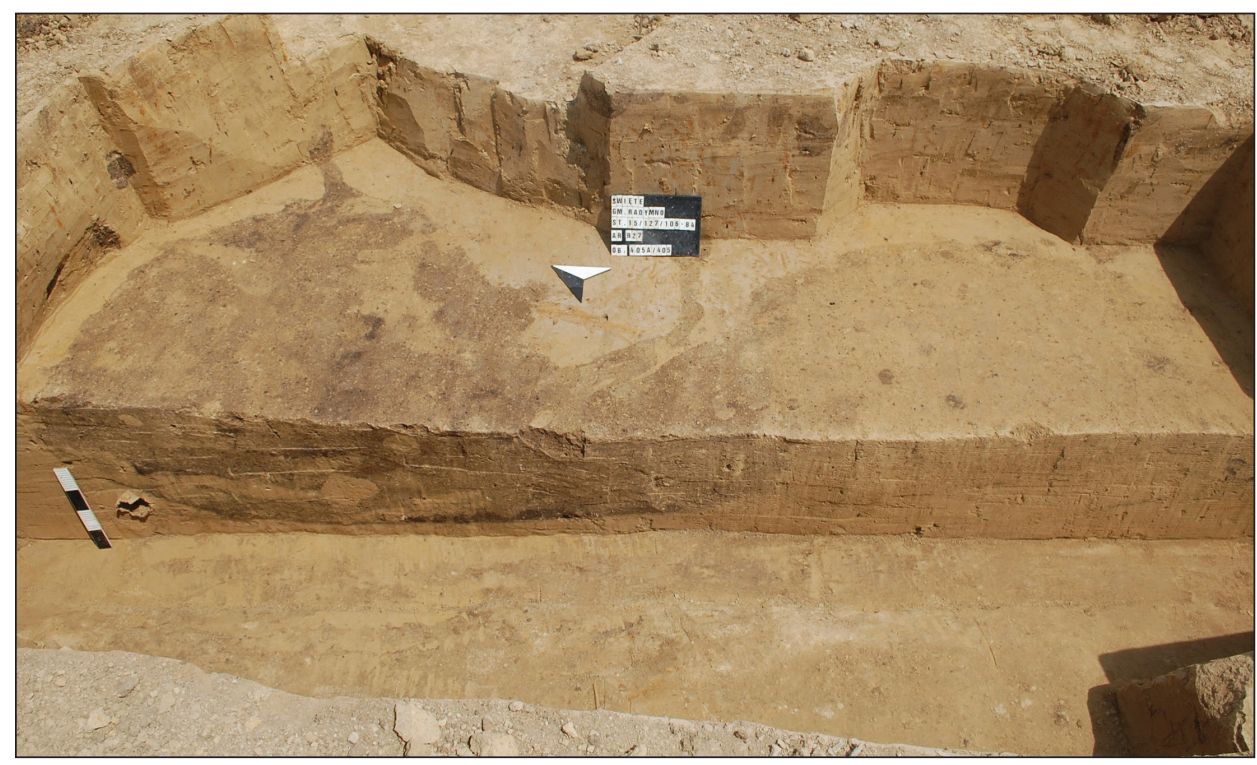

Fig. 13. Święte, site 15. Grave 405A: entrance pit and niche during exploration. Photo M. Mądzik 


\section{Grave 407}

\begin{tabular}{|l|l|l|l|}
\hline Chronology & Poz-90882: 3855 \pm 35 BP, 2452-2214 BC \\
\hline Construction type & \multirow{2}{*}{ niche? } & Number of burials & 1 \\
\cline { 3 - 4 } & & Sex & female \\
\cline { 3 - 4 } & \multirow{2}{*}{$\begin{array}{l}\text { Age } \\
\text { Niche grave } \\
\text { dimensions (m) }\end{array}$} & Orientation & N0-50 years \\
\hline Depth $(\mathrm{m})$ & 0.2 & Deviation & $20^{\circ}$ \\
\hline Niche orientation & N-S & $\begin{array}{l}\text { Placement of head/ } \\
\text { body/lower limbs }\end{array}$ & B/B/L \\
\cline { 3 - 4 } & & Lower limbs & 6 \\
\cline { 3 - 4 } & & Upper limbs & $?$ \\
\hline
\end{tabular}

Only the base part of the feature was preserved - its fill documented with a layer of $20 \mathrm{~cm}$ thickness. On account of this problem the particular details of grave construction are impossible to establish. The presence of a rectangular type of exit from the south-west suggests the feature had a niche character (Fig. 14: A). The base of the entrance pit would have been at that time located at the level of the niche bottom - just as in the case of grave 405A. The outline of the pit, set in the base part, was irregular in shape and approximate to an oval. The fill was made up of homogenous dark brown earth. At the bottom of the niche a poorly preserved burial showed a supine individual in a contracted position with the lower limbs turned to the left (Fig. 14: A; 15). Furnishings constituted two vessels that were placed by the lower limbs.

\section{Inventory:}

1. A small undecorated pot plant beaker. Walls somewhat profiled. Bottom not outlined, concave. Dimensions: height $-6.3 \mathrm{~cm}$, spout diameter $-8.3 \mathrm{~cm}$, bottom diameter $-6.6 \mathrm{~cm}$. Fig. 14: 1 .

2. The lower part of the vessel, a bipartite beaker or amphora. Bottom not outlined. Dimensions: bottom diameter $-5.0 \mathrm{~cm}$. Fig. 14: 2 . 

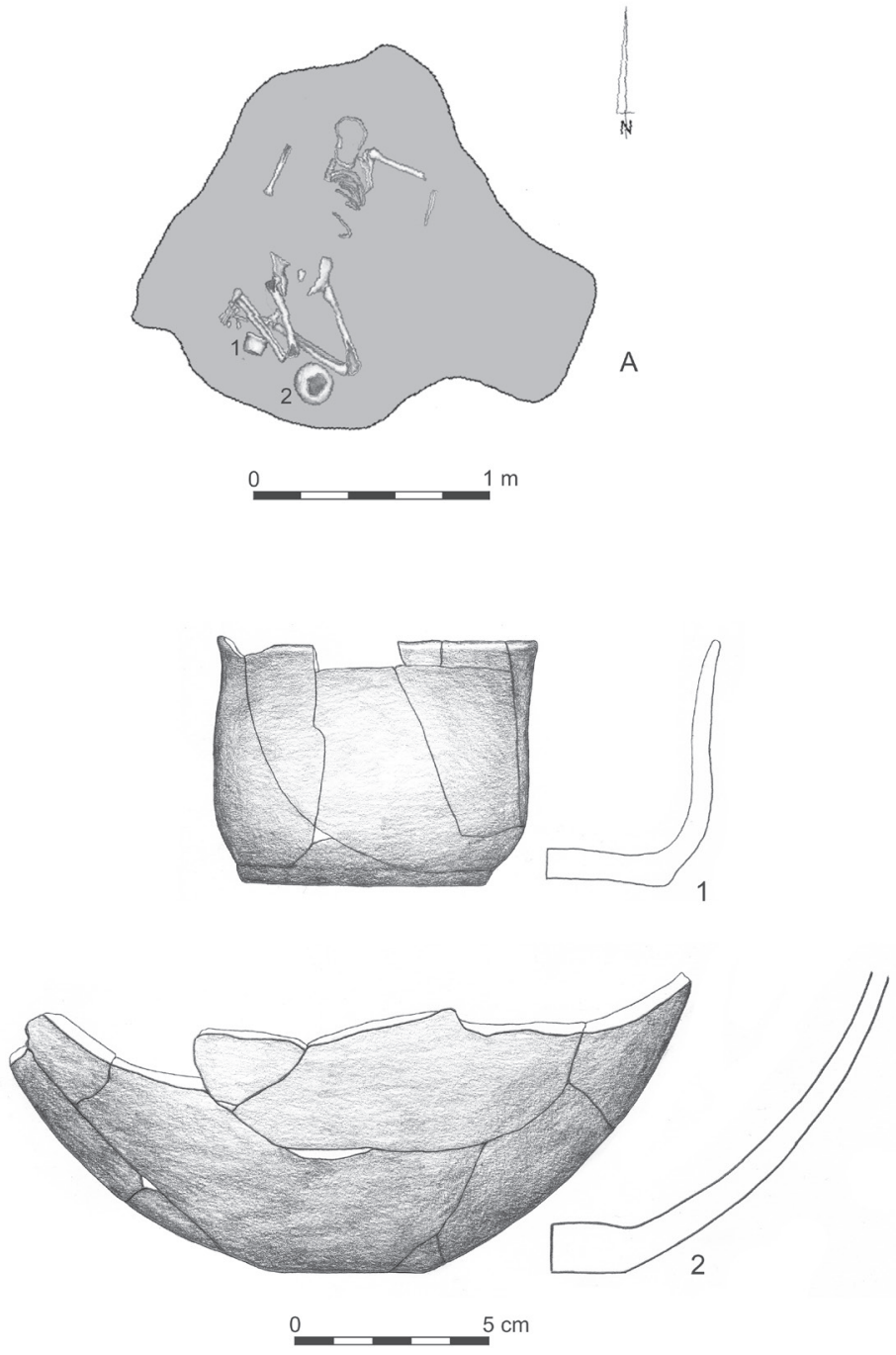

Fig. 14. Święte, site 15. Grave 407: A - burial level, 1-2 - inventory. Drawing M. Podsiadło 


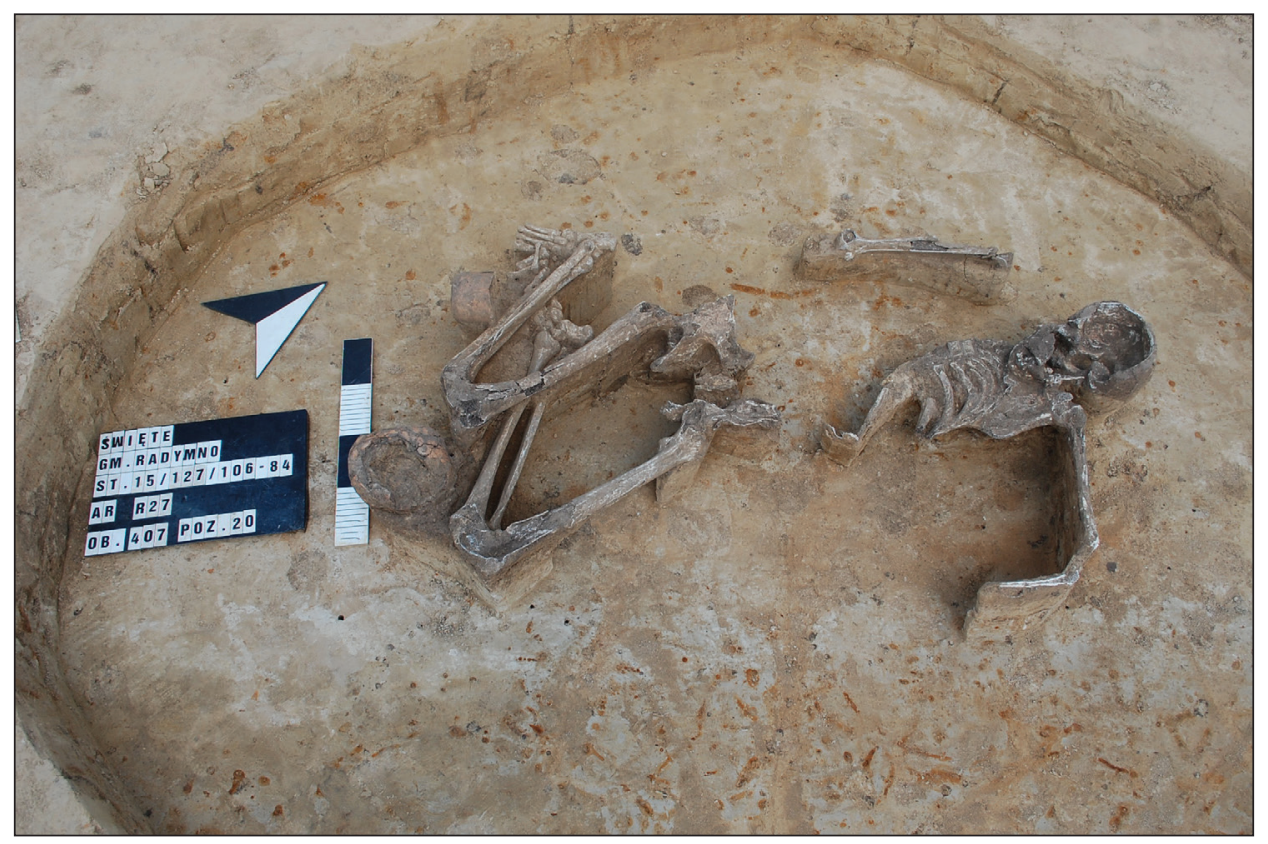

Fig. 15. Święte, site 15. Grave 407: burial level. Photo M. Mądzik

\section{Grave 408}

\begin{tabular}{|c|c|c|c|}
\hline Chronology & \multicolumn{3}{|c|}{ Poz-90780: 3890 35 BP, 2460-2340 BC } \\
\hline \multirow[t]{3}{*}{ Construction type } & \multirow[t]{3}{*}{ niche } & Number of burials & 2 \\
\hline & & Sex & $\begin{array}{l}\text { A. female } \\
\text { B. female } \\
\end{array}$ \\
\hline & & Age & $\begin{array}{l}\text { A. } 30-40 \text { years } \\
\text { B. } 20-30 \text { years } \\
\end{array}$ \\
\hline $\begin{array}{l}\text { Niche grave } \\
\text { dimensions (m) }\end{array}$ & $2.45 \times 2.4$ & Orientation & $\begin{array}{l}\text { A. ? } \\
\text { B. NW-SE }\end{array}$ \\
\hline Depth $(\mathrm{m})$ & ca. 1.2 & Deviation & \begin{tabular}{|l|} 
A. - \\
B. $5^{\circ}$ \\
\end{tabular} \\
\hline \multirow[t]{3}{*}{ Niche orientation } & \multirow[t]{3}{*}{$\mathrm{N}-\mathrm{S}$} & $\begin{array}{l}\text { Placement of head/ } \\
\text { body/lower limbs }\end{array}$ & \begin{tabular}{|l|} 
A.- \\
B. L/L/L \\
\end{tabular} \\
\hline & & Lower limbs & $\begin{array}{l}\text { A. }- \\
\text { B. } 3 \\
\end{array}$ \\
\hline & & Upper limbs & $\begin{array}{l}\text { A. }- \\
\text { B. D }\end{array}$ \\
\hline
\end{tabular}

A grave with a niche construction. The entrance pit was not preserved (the shape of the niche and location of burials indicates that it may have been situated from the east). The fill of the niche was multilayered. The main part was of yellow and light brown earth. On the periphery of the western part of the pit a dark brown 

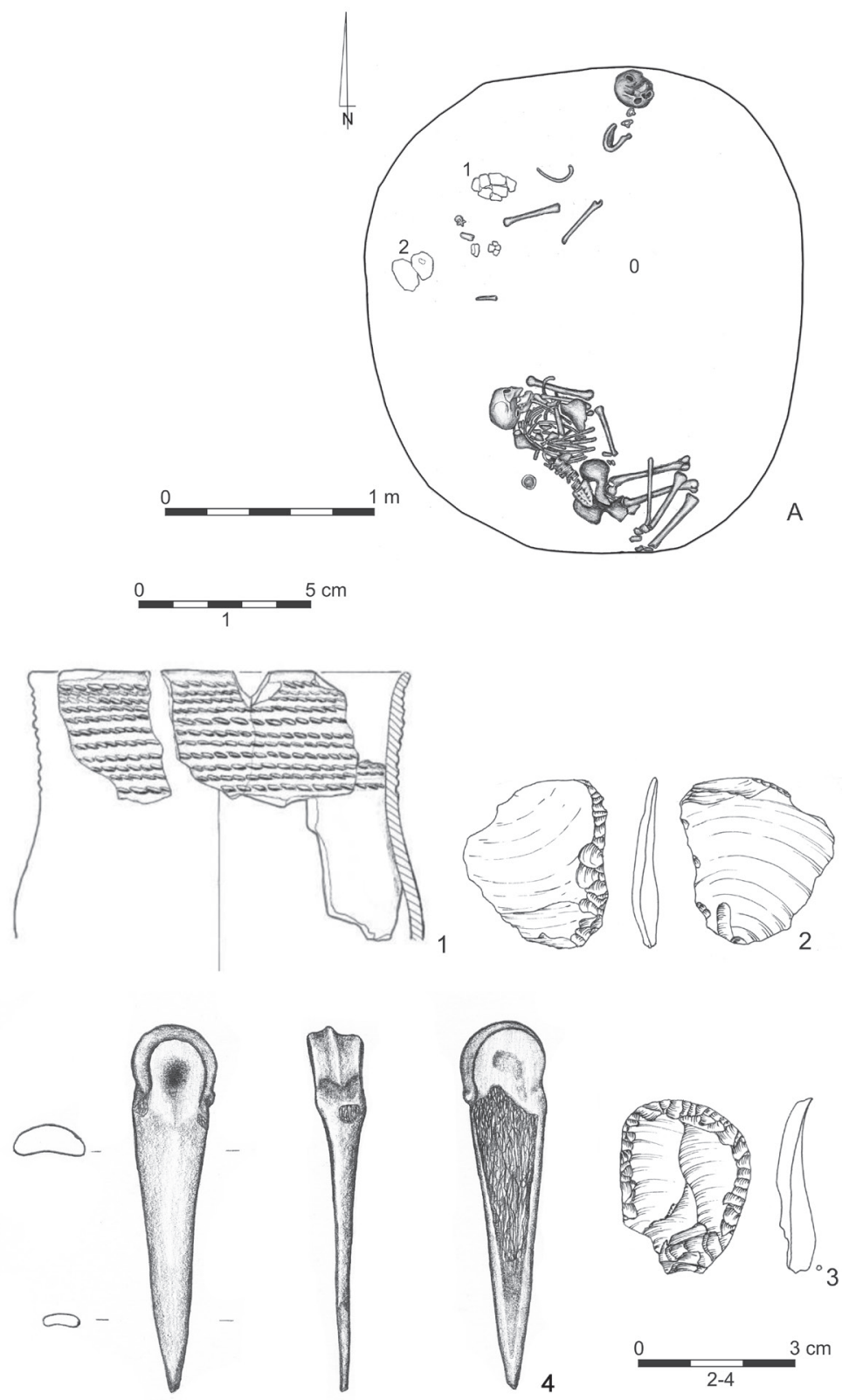

Fig. 16. Święte, site 15. Grave 408: A - burial level, 1-4 - inventory. Drawing A. Dziedzic, M. Podsiadło, A. Falis

earth was recorded. This type of fill testifies to the collapse of the niche ceiling. At the bottom of the feature, in the southern part a relatively well preserved intern- 


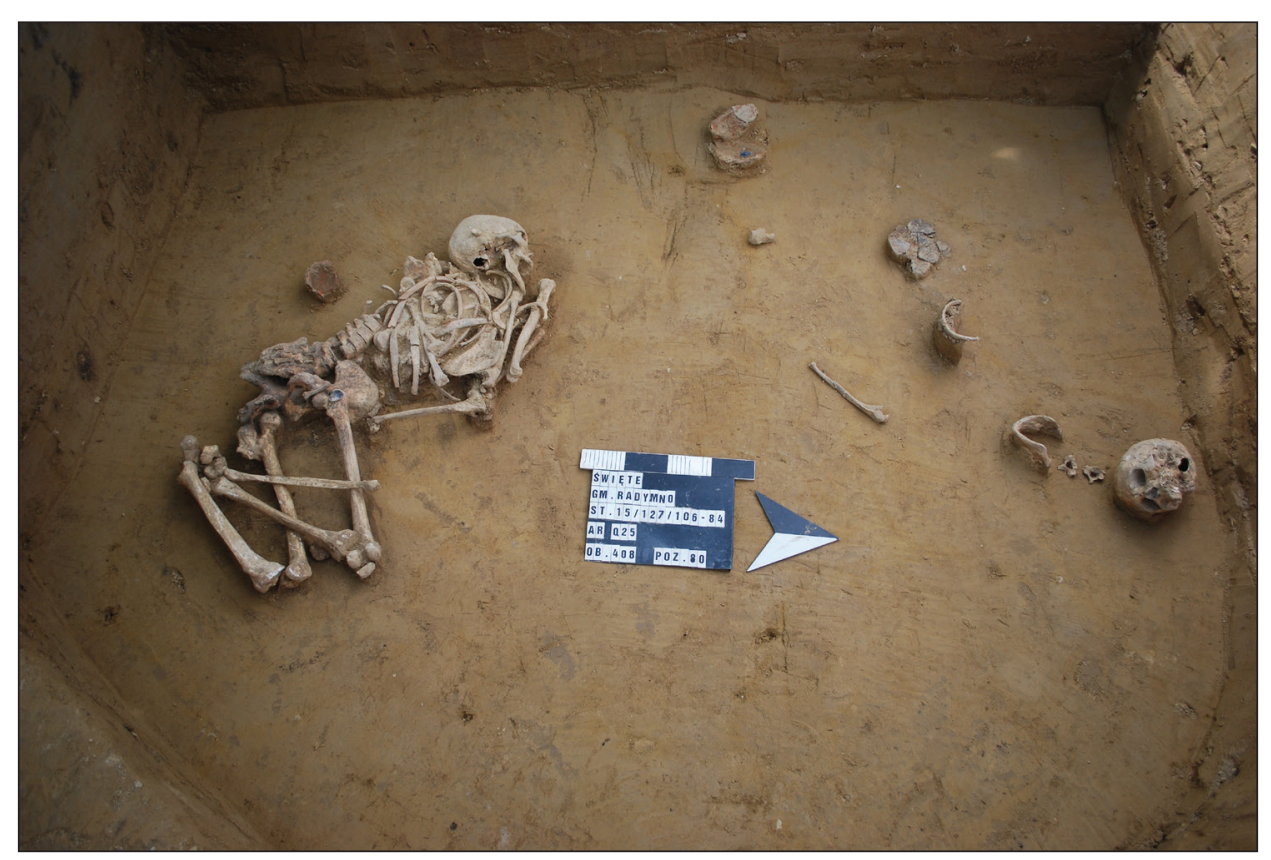

Fig. 17. Święte, site 15. Grave 408: burial level. Photo M. Mądzik

ment of a woman (skeleton B) was discovered, placed in the contracted position on its left side (Fig. 16: A; 17). At the base of the thigh bone a flint endscraper was found and by the bones of the spine, small vessels. In the northern part however the disarticulated remains of another individual of female sex (skeleton A) were scattered. Fragment of two vessels and a flint scraper were found. Moreover, there at the level of the burial an awl and an animal bone were found.

\section{Inventory:}

1. A large S-profile beaker preserved in fragments, embellished all along the small neck with 13 rows of Z-twisted cord imprints. Dimensions: spout diameter approx. $11 \mathrm{~cm}$, belly diameter - approx. $12 \mathrm{~cm}$. Fig. 16: 1 .

2. A poorly preserved vessel - a large beaker or amphora. On the fragment of the lower part of the small neck there are three rows of Z-twisted cord imprints.

3 . An awl made out of the bones of a sheep's metatarsal. The surface of the vessel clearly smoothed. Dimensions: length $7.2 \mathrm{~cm}$, base width $-1.6 \mathrm{~cm}$. Fig. 16: 4 .

4. A somewhat broken (perhaps by an attempt to intentionally separate) metatarsal of a young goat or shape. Dimensions: length $-11.8 \mathrm{~cm}$.

5. A regular endscraper on a negative flake of cretaceous eastern flint. Dimensions: $3.3 \times 2.6 \times 0.5 \mathrm{~cm}$. Fig. $16: 3$.

6. A small scraper on a cretaceous eastern flake, finally retouched, half steep on the right side. Dimensions: $3.2 \times 2.8 \times 0.4 \mathrm{~cm}$. Fig. 16: 2 . 


\section{Grave 409}

\begin{tabular}{|c|c|c|c|}
\hline Chronology & \multicolumn{3}{|c|}{ Poz-90781: 3990 \pm 30 BP, 2565-2473 BC } \\
\hline \multirow[t]{3}{*}{ Construction type } & \multirow[t]{3}{*}{ niche } & Number of burials & 1 \\
\hline & & Sex & male \\
\hline & & Age & $>20$ years \\
\hline $\begin{array}{l}\text { Niche grave } \\
\text { dimensions (m) }\end{array}$ & $1.15 \times 1.0$ & Orientation & W-E \\
\hline Depth (m) & 0.6 & Deviation & \\
\hline \multirow[t]{3}{*}{ Niche orientation } & \multirow[t]{3}{*}{ W-E } & $\begin{array}{l}\text { Placement of head/ } \\
\text { body/lower limbs }\end{array}$ & ?/B?/R \\
\hline & & Lower limbs & 2 \\
\hline & & Upper limbs & A.? \\
\hline
\end{tabular}

A feature with a niche construction. The entrance pit was situated from the south of the niche. Most likely the base of the niche and entrance pit were on the same level. The niche was oval in shape and its fill was heterogeneous, made up of dark grey brown earth and yellow loess. The burial was poorly preserved - only the lower limbs and fragments of the upper right limb were preserved (Fig. 18; 19). Lack of furnishings.

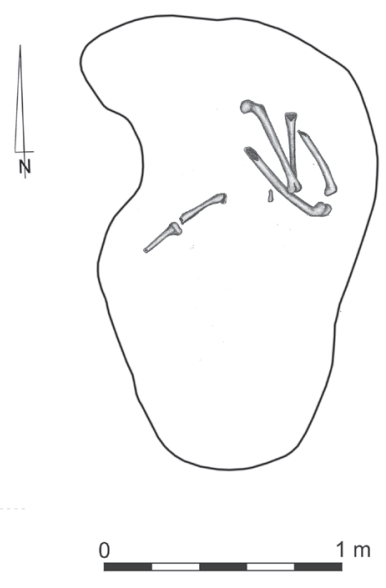

Fig. 18. Święte, site 15. Grave 409: burial level. Drawing M. Podsiadło 


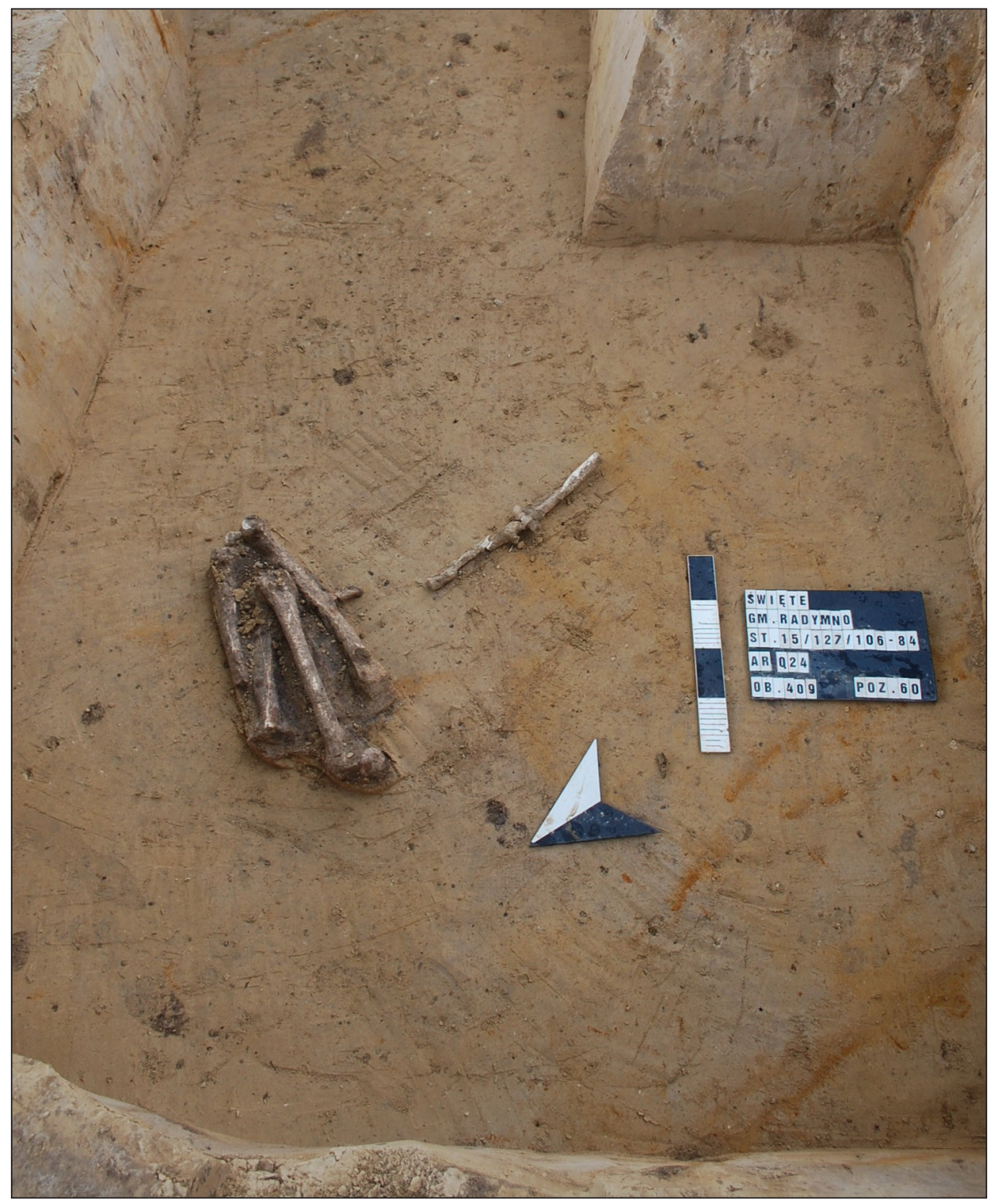

Fig. 19. Święte, site 15. Grave 409: burial level. Photo M. Mądzik 


\section{Grave 423}

\begin{tabular}{|c|c|c|c|}
\hline \multicolumn{4}{|l|}{ Chronology } \\
\hline \multirow[t]{3}{*}{ Construction type } & \multirow[t]{3}{*}{ pit? } & Number of burials & 2 \\
\hline & & Sex & $\begin{array}{l}\text { A. ? } \\
\text { B. ? }\end{array}$ \\
\hline & & Age & $\begin{array}{l}\text { Infans I }(6-7 \text { years })+ \\
\text { infans I (2-3 years) }\end{array}$ \\
\hline $\begin{array}{l}\text { Niche grave } \\
\text { dimensions }(m)\end{array}$ & $?$ & Orientation & $\begin{array}{l}\text { A. ? } \\
\text { B.? }\end{array}$ \\
\hline Depth (m) & 0.05 & Deviation & $\begin{array}{l}\text { A. - } \\
\text { B. - }\end{array}$ \\
\hline \multirow[t]{5}{*}{ Niche orientation } & \multirow[t]{5}{*}{$?$} & $\begin{array}{l}\text { Placement of head/ } \\
\text { body/lower limbs }\end{array}$ & $\begin{array}{l}\text { A. ? } \\
\text { B. ? }\end{array}$ \\
\hline & & \multirow[t]{2}{*}{ Lower limbs } & A. ? \\
\hline & & & B. ? \\
\hline & & \multirow[t]{2}{*}{ Upper limbs } & A. ? \\
\hline & & & B. ? \\
\hline
\end{tabular}

The level of the internment was just under the base of the humus. For this reason it was not possible to establish the type of construction, extent of pit and details of burial. The human remains were highly disarticulated and partially destroyed (Fig. 20;21). At the bones there were discovered a small number of CWC ceramic fragments - the remains of the destroyed vessel.

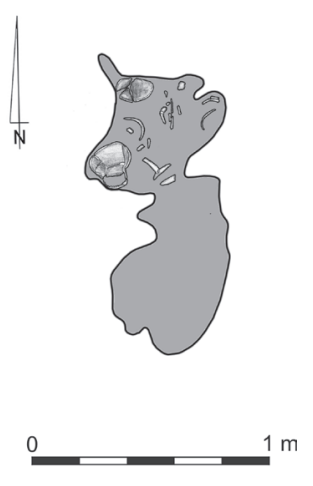

Fig. 20 . Święte, site 15. Grave 423: burial level. Drawing M. Podsiadło 


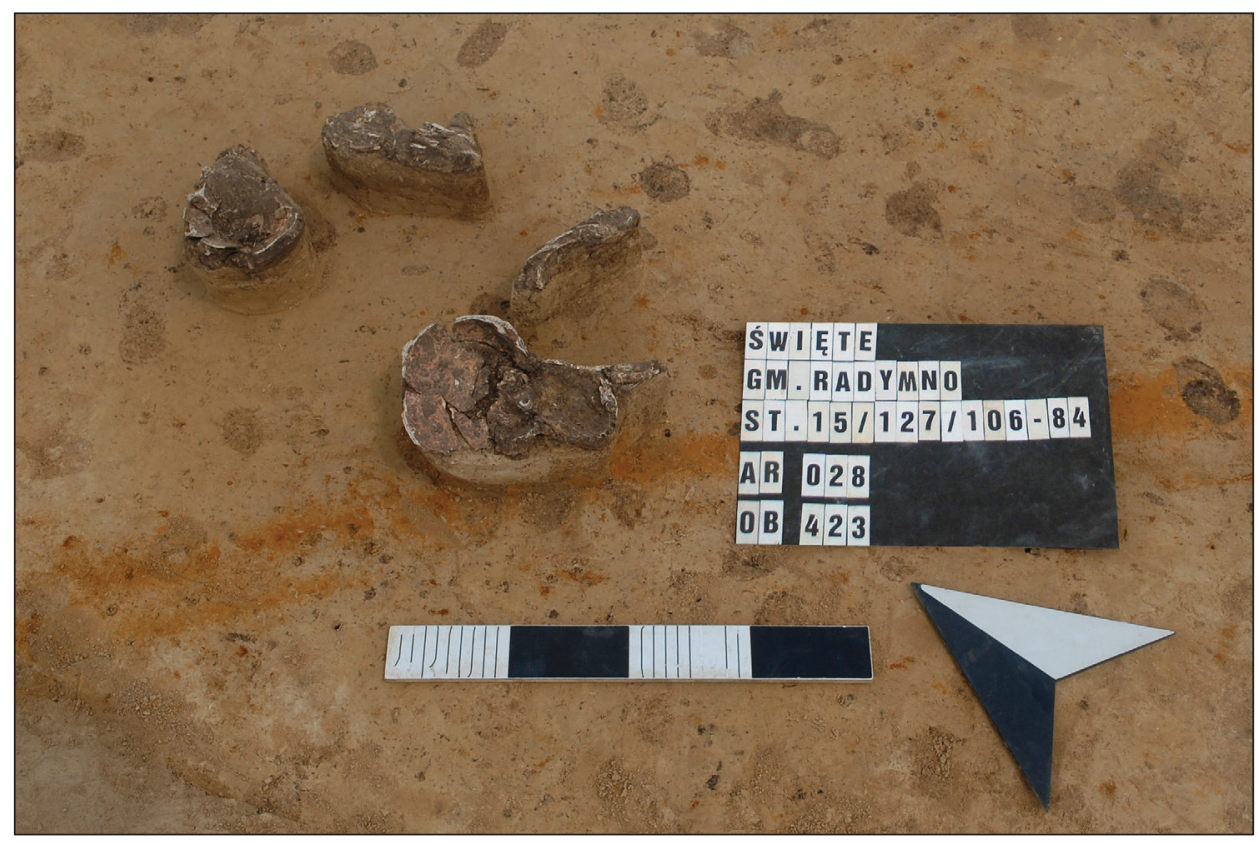

Fig. 21. Święte, site 15. Grave 423: burial level. Photo M. Mądzik

\section{Feature 426}

\begin{tabular}{|l|l|l|l|}
\hline Chronology & \multicolumn{3}{|l|}{} \\
\hline Construction type & \multirow{2}{*}{ pit } & Number of burials & 0 \\
\cline { 3 - 4 } & & Sex & - \\
\cline { 3 - 4 } & & Age & - \\
\hline $\begin{array}{l}\text { Niche grave } \\
\text { dimensions (m) }\end{array}$ & $0.58 \times 0.46$ & Orientation & - \\
\hline Depth (m) & 0.18 & Deviation & - \\
\hline Niche orientation & W-E & $\begin{array}{l}\text { Placement of head/ } \\
\text { body/lower limbs }\end{array}$ & - \\
\cline { 3 - 4 } & & Lower limbs & - \\
\hline & & Upper limbs & - \\
\hline
\end{tabular}

A small shallow pit, oval in horizontal profile, basin-like in vertical profile (Fig. 22: A, B). The fill was made up of a homogenous grey brown earth. In its middle part a partially preserved vessel was found. No bones were discovered in the burial. 


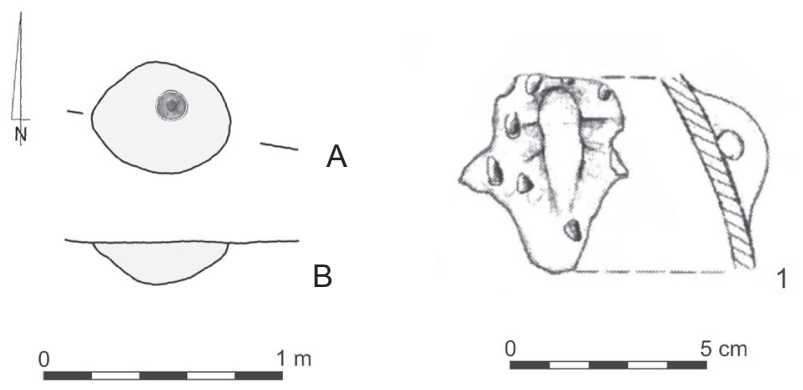

Fig. 22 . Święte, site 15. Feature 426: A - plan, at bottom, B - vertical profile, 1 - vessel fragment. Drawing N. Podsiadło, A. Falis

\section{Inventory:}

1. Fragment of a large amphora with one preserved horizontally pierced handle. At the level of the handles a decoration of uneven hollows-imprints. The bottom not outlined, flat. Fig. 22: 1.

2. Two fragments of a belly of a thin-walled vessel from the CWC.

\section{Grave 427}

\begin{tabular}{|l|l|l|l|}
\hline Chronology & \multicolumn{3}{|l|}{} \\
\hline Construction type & \multirow{2}{*}{ pit? } & Number of burials & 1 \\
\cline { 3 - 4 } & & Sex & $?$ \\
\cline { 3 - 4 } & & Age & $5-6$ years \\
\hline $\begin{array}{l}\text { Niche grave } \\
\text { dimensions (m) }\end{array}$ & $1.75 \times 1.2$ & Orientation & N-S \\
\hline Depth (m) & 0.55 & Deviation & $0^{\circ}$ \\
\hline Niche orientation & N-S & $\begin{array}{l}\text { Placement of head/ } \\
\text { body/lower limbs }\end{array}$ & R/R/R \\
\cline { 3 - 4 } & & Lower limbs & 7 \\
\hline & & Upper limbs & D? \\
\hline
\end{tabular}

The grave type is difficult to determine (Fig. 23: B). The fill is of a round and dark brown coloured earth with numerous additions of yellow loess parcels. The internment was placed in an untypical manner for Lesser Poland CWC: on the right side, head turned north (Fig. 23: A). A small beaker was placed by the back of the deceased.

\section{Inventory:}

1. A small hourglass beaker, embellished on the upper part with 5-6 horizontal rows of Z-twisted thick cord imprints. Bottom not outlined. Dimensions: height $8.0 \mathrm{~cm}$, spout diameter $-7.7 \mathrm{~cm}$, bottom diameter $-6.1 \mathrm{~cm}$. Fig. 23: 1 . 

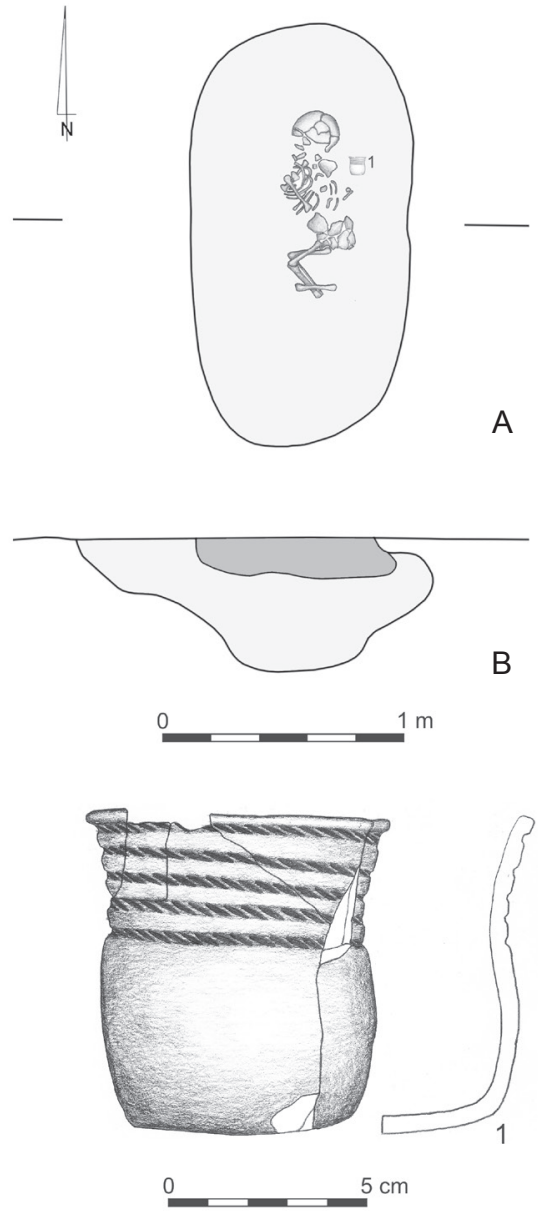

Fig. 23. Święte, site 15. Grave 427: A - burial level, B - vertical profile, 1 - inventory. Drawing M. Podsiadło 


\section{Grave 431A}

\begin{tabular}{|l|l|l|l|}
\hline Chronology & \multicolumn{2}{|l|}{} \\
\hline Construction type & \multirow{2}{*}{ niche } & Number of burials & 1 \\
\cline { 3 - 4 } & & Sex & male \\
\cline { 3 - 4 } & & Age & $40-50$ years \\
\hline $\begin{array}{l}\text { Niche grave } \\
\text { dimensions (m) }\end{array}$ & $2.6 \times 1.7$ & Orientation & W-E \\
\hline Depth (m) & ca. 1.2 & Deviation & $0^{\circ}$ \\
\hline Niche orientation & W-E & $\begin{array}{l}\text { Placement of head/ } \\
\text { body/lower limbs }\end{array}$ & R?/R//R \\
\cline { 3 - 4 } & & Lower limbs & $6 ?$ \\
\cline { 3 - 4 } & & Upper limbs & B? \\
\hline
\end{tabular}

The entrance pit was situated south of the niche. It was oval and its fill constituted dark brown earth. Between the shaft and the niche there was a narrowing - a corridor about $40 \mathrm{~cm}$ wide and $50 \mathrm{~cm}$ long (Fig. 24: B). The large niche was oval and its fill was analogical to the layers of earth in the entrance shaft. At the bottom of the pit there lay a poorly preserved internment, individual supine, head and lower limbs turned towards the right (Fig. 24: C; 28). Some of the individual's teeth were found elsewhere in the vicinity of the axe.

\section{Inventory:}

1. A small broad-mouth beaker, embellished on the small neck and on the upper part of the belly with a combination of vertical rows of herringbone imprints as well as triangular stamps. Bottom lightly outlined, concave. Dimensions: height $-10.8 \mathrm{~cm}$, spout diameter - ca. $10.5 \mathrm{~cm}$, belly diameter $-13.1 \mathrm{~cm}$, bottom diameter $-3.9 \mathrm{~cm}$. Fig. $25: 1$.

2. Large, undecorated S-profile beaker. The bottom outlined, flat. In the sample from the fill and vessel the presence was confirmed of an emmer chaff base (Triticum dicoccon) and that of a spelt spikelet (Triticum spelta) as well as two unidentified granulomae of grain ${ }^{3}$. Dimensions: height $-20.1 \mathrm{~cm}$, spout diameter $10.4 \mathrm{~cm}$, belly diameter $-17.6 \mathrm{~cm}$, bottom diameter $-6.3 \mathrm{~cm}$. Fig. $25: 2$.

3. A rhomboid battle-axe made out of gabbro ${ }^{4}$, symmetrical and carefully finished by smoothing all surfaces. Traces of use are visible on the edge of the blade and on the surface of the butt. The blade is slightly asymmetrical. The opening is drilled from both sides. The butt is round, slightly convex. Dimensions: length $-11.4 \mathrm{~cm}$, blade width $-4.1 \mathrm{~cm}$, butt diameter $-2.5 \mathrm{~cm}$, width $5.2 \mathrm{~cm}$, opening diameter $-2.1 \mathrm{~cm}$. Fig. 26: 3 .

4. The chisel is from a cattle radial bone, cracked along its edge from the nearest end. Dimensions: length $-13.8 \mathrm{~cm}$, blade width $-1.5 \mathrm{~cm}$, base width $-3.1 \mathrm{~cm}$. Fig. 26: 4.

\footnotetext{
${ }^{3}$ Paleobotanical analysis conducted by R. Stachowicz-Rybka and Z. Tomczyńska.

${ }^{4}$ Information courtesy of Dr. Agnieszka Wójcik.
} 


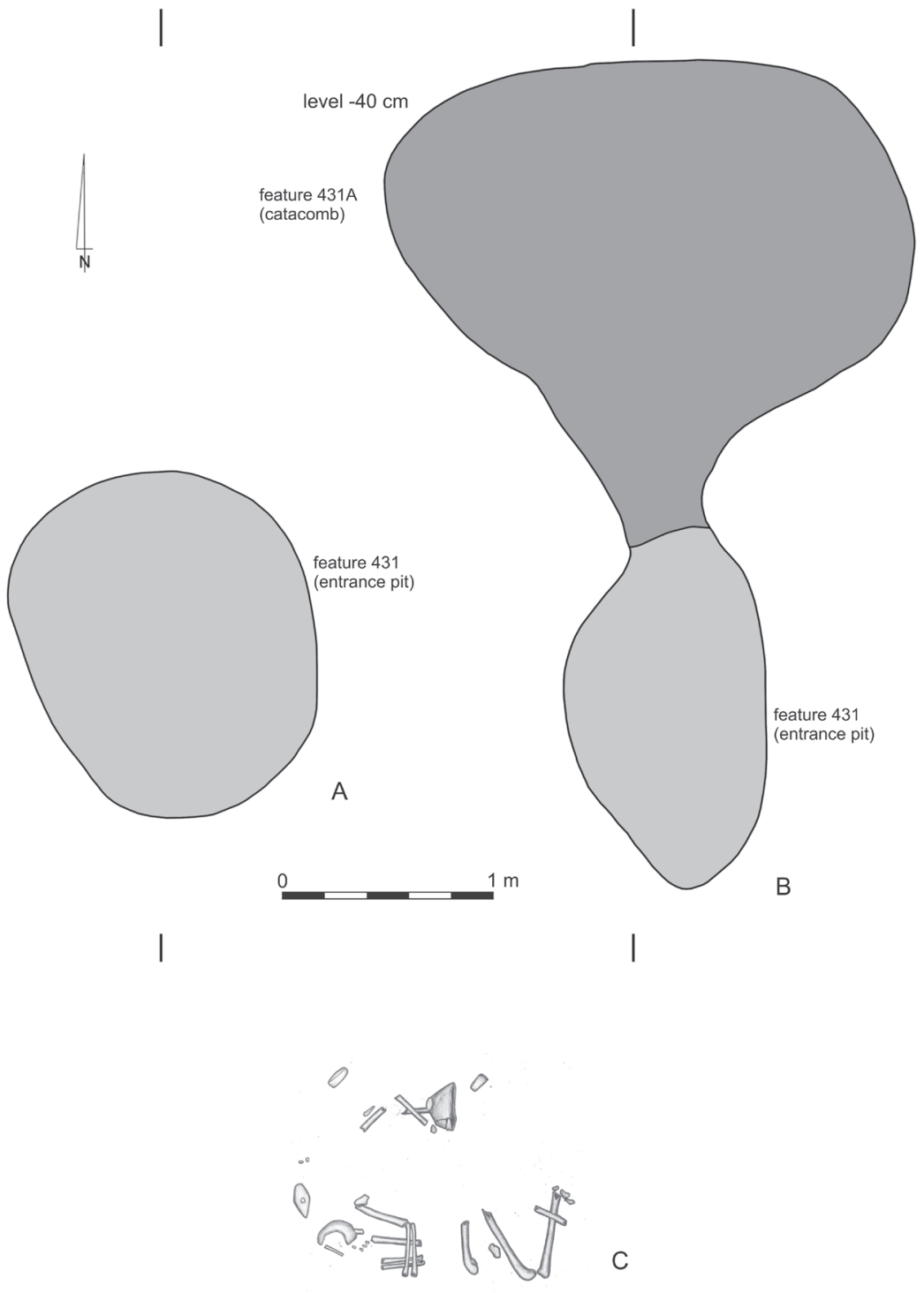

Fig. 24. Święte, site 15. Grave 431A: A - plan, discovery level, B - plan, depth of $40 \mathrm{~cm}$, $\mathrm{C}$ - burial level. Drawing M. Podsiadło

5. Flat, cretaceous eastern flint rectangular axe. The narrow sides formed by a series of chips from one of the sides of the edge. The surfaces were formed in the 

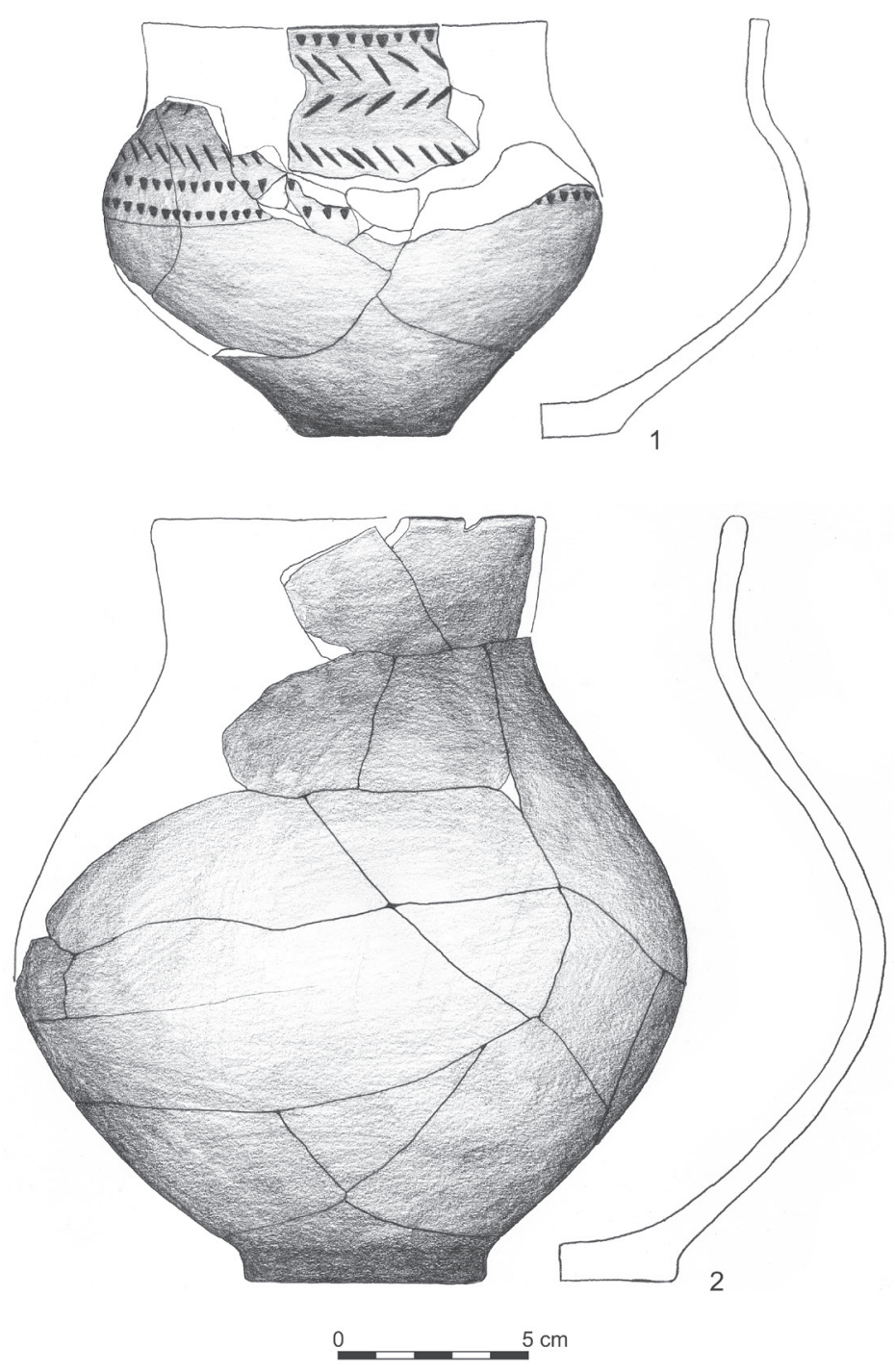

Fig. 2 5. Święte, site 15. Grave 431A: 1-2 - inventory. Drawing M. Podsiadło

main by a series of flake chips from the side edge. The part at the blade is polished on a relatively narrow surface. The butt formed. Dimensions: length $-7.3 \mathrm{~cm}$, blade width $-3.6 \mathrm{~cm}$, butt width $-2.8 \mathrm{~cm}$, thickness $-1.4 \mathrm{~cm}$. Fig. 27: 5 .

6. Eastern cretaceous dagger blade. Retouched at the edge, steep and half steep in the distal part. In the proximal part, a fragment of cortical surface. Dimensions: $5.5 \times 1.9 \times 0.4 \mathrm{~cm}$. Fig. $27: 6$. 

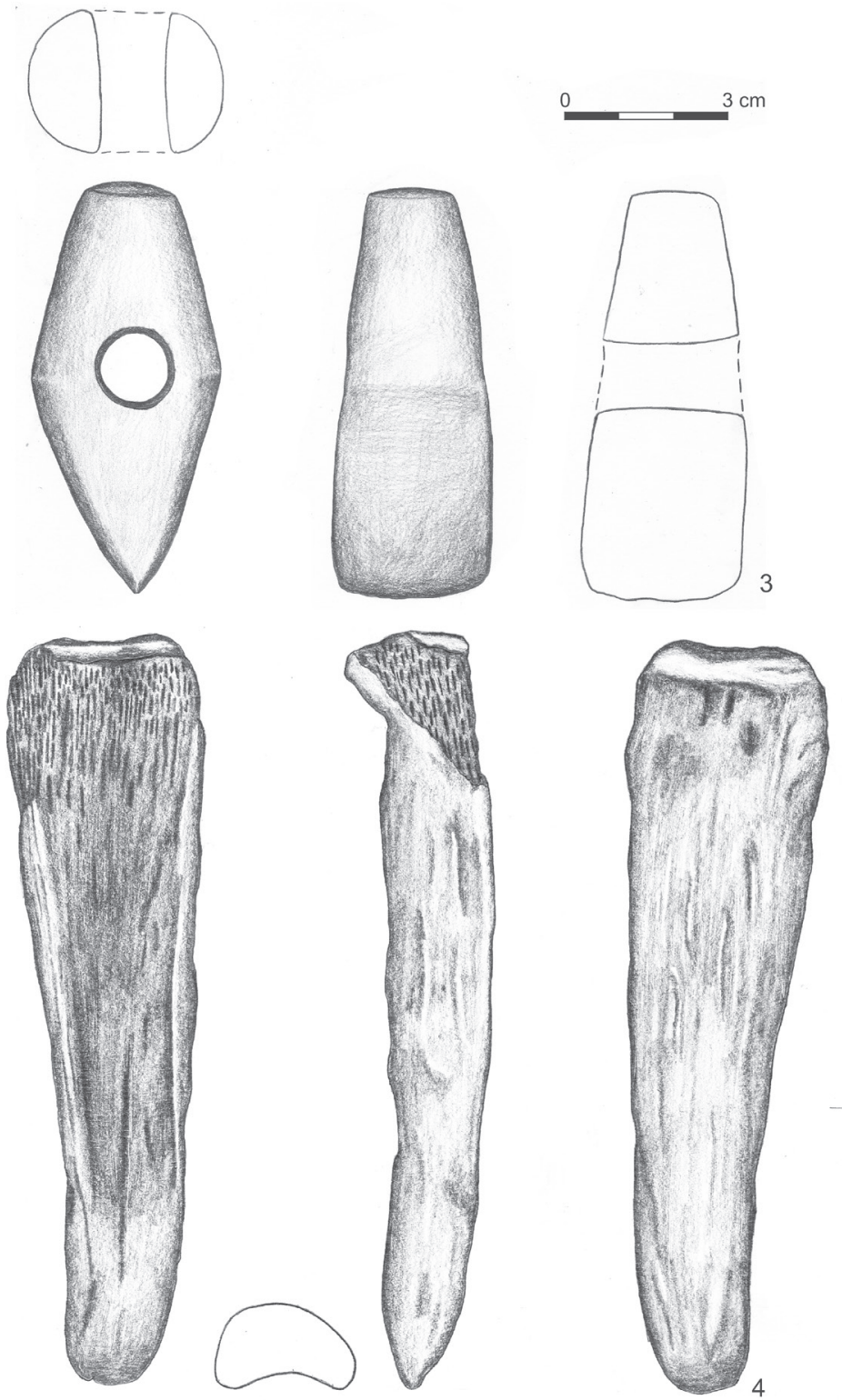

Fig. 26 . Święte, site 15. Grave 431A: 3-4 - inventory. Drawing M. Podsiadło

7. Świeciechów flint flake. The negative side partially cortical in an aeolian natural worn sheen. Dimensions: $2.2 \times 2.9 \times 0.5 \mathrm{~cm}$. Fig. $27: 7$.

8. Rectangular stone axe made out of amphibolites, bent into an arch with an oblong profile Most likely made out of a naturally ground piece of rock, using its 

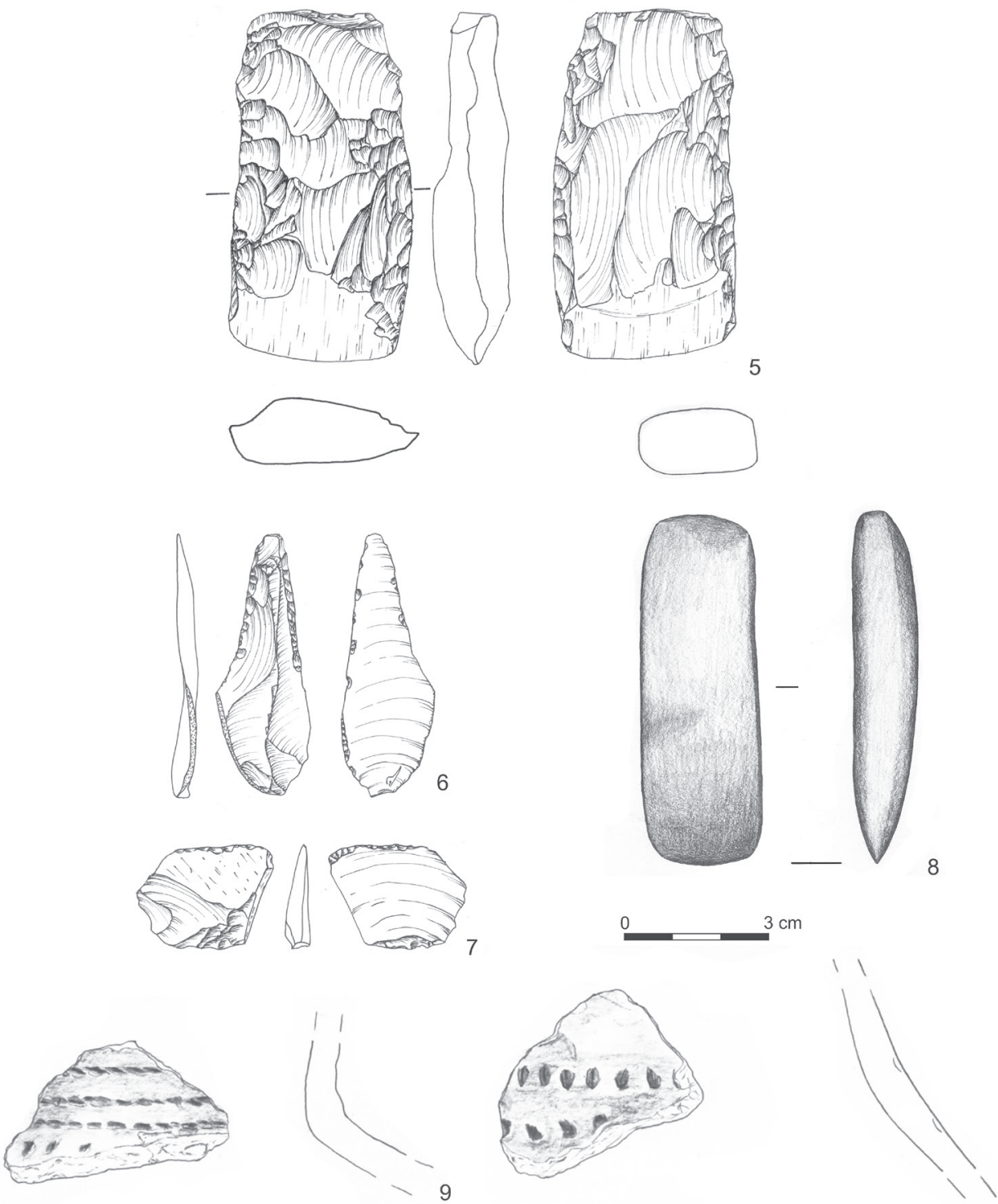

10
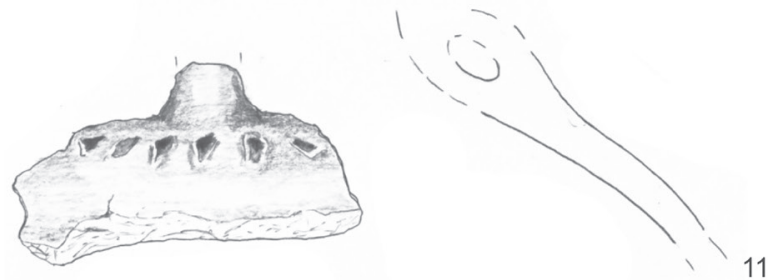

Fig. 27. Święte, site 15. Grave 431A: 5-11 - inventory. Drawing A. Dziedzic, M. Podsiadło, E. Włodarczak 


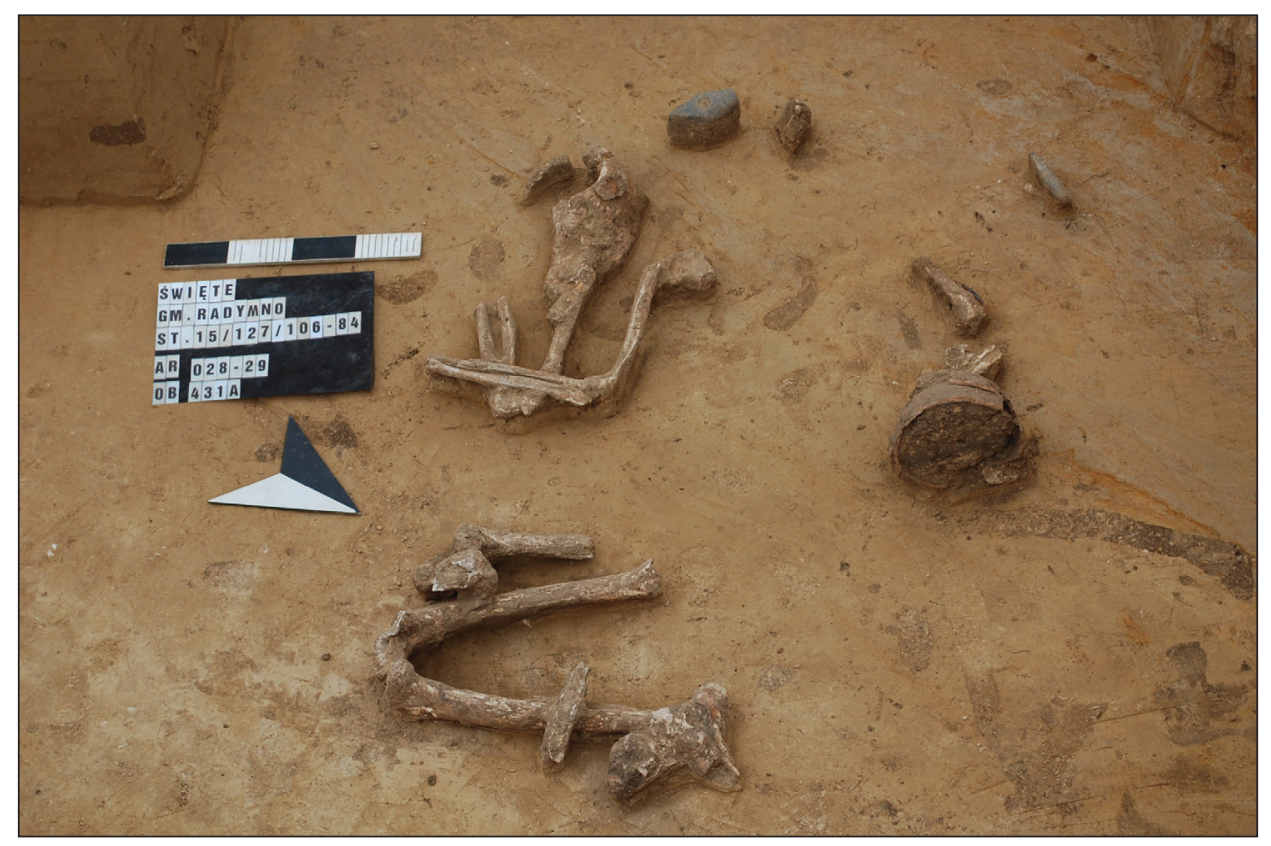

Fig. 28. Święte, site 15. Grave 431A: burial level. Photo M. Mądzik

original shape. Polished along all its surfaces, blade asymmetrical. The butt likely tapered, partially smoothed. Dimensions: length $-11.0 \mathrm{~cm}$, width of blade $3.2 \mathrm{~cm}$, butt width $-2.9 \mathrm{~cm}$, thickness $-2.1 \mathrm{~cm}$. Fig. $27: 8$.

Moreover, at the bottom of the feature there were found $75 \mathrm{CWC}$ fragments of ceramic ware. In this collection the fragments of two amphorae and two vessels of an unidentified type (Fig. 27: 9-11) were distinguished. The presence of cord embellishment was established (Z-twist imprints) and rows of uneven oval imprints.

\section{DISCUSSION}

The majority of CWC graves were discovered in the eastern, partially surveyed part of the site. Only feature 173 was located in the central part. In the eastern section of the grave there were three concentrations (I - features 408 and 409, II - features 405A and 407 III - features 423, 426, 427 and 431A). It cannot be excluded that the first two were part of one rather vast area used for funerary purposes, for there is a band of unsurveyed land between them, some $10 \mathrm{~m}$ wide (Fig. 2). Neither 


\begin{tabular}{|c|c|c|c|c|c|c|c|c|c|}
\hline 己ٌ & & & & 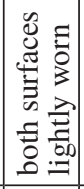 & & & 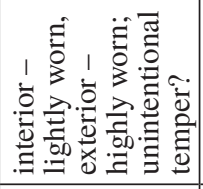 & & 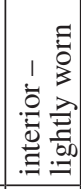 \\
\hline 节 & 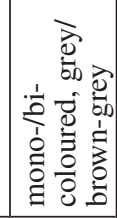 & 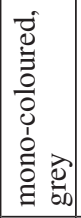 & 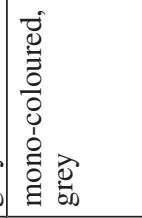 & 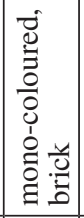 & 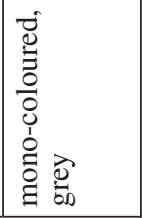 & 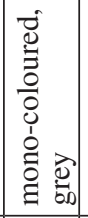 & 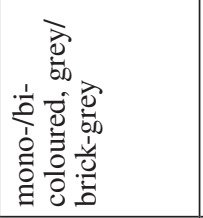 & 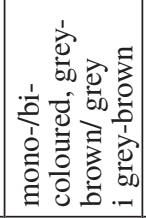 & 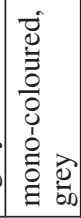 \\
\hline 竎 & 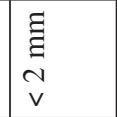 & 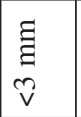 & 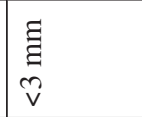 & \begin{tabular}{|l|} 
g \\
है \\
v
\end{tabular} & 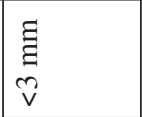 & \begin{tabular}{|l|}
$g$ \\
g. \\
v \\
\end{tabular} & \begin{tabular}{|l|}
$\Xi$ \\
$\bar{\Xi}$ \\
$\mathrm{v}$
\end{tabular} & $\begin{array}{l}\text { E } \\
\text { ह } \\
\text { ข } \\
\text { v }\end{array}$ & \begin{tabular}{|l|} 
I \\
ป \\
v
\end{tabular} \\
\hline 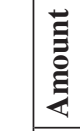 & 总 & $\stackrel{\varrho}{\Xi}$ & 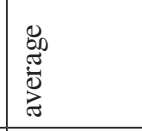 & 总 & 总 & 总 & 异 & 杰 & 总 \\
\hline 产 &  & 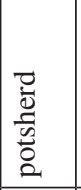 & 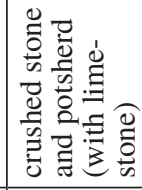 & 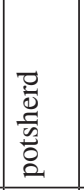 & 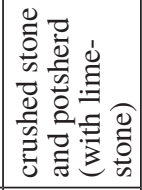 & 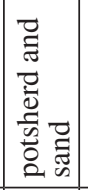 & $\begin{array}{l}\vec{E} \\
\text { E్ }\end{array}$ & 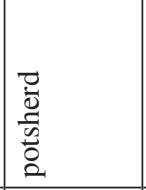 & 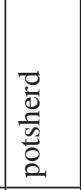 \\
\hline 离 & 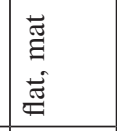 & 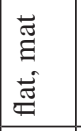 & 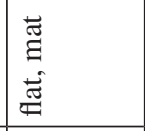 & 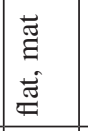 & 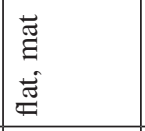 & 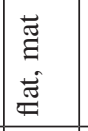 & 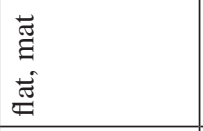 & 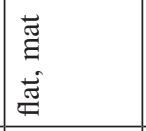 & 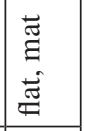 \\
\hline U & قُ & 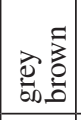 & 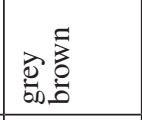 & 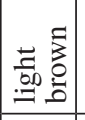 & 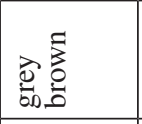 & 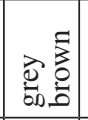 & 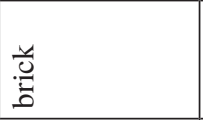 & है & 荡总 \\
\hline 离 & 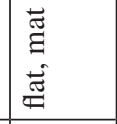 & 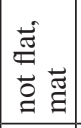 & 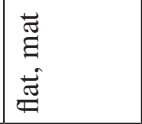 & 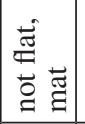 & 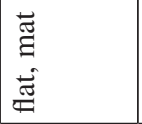 & $\begin{array}{l}\vec{\Xi} \\
\Xi \\
\stackrel{\Xi \Xi \Xi}{\leftrightarrows}\end{array}$ & 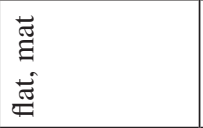 & 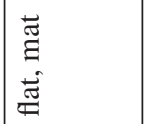 & 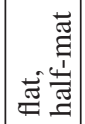 \\
\hline U⿺辶ِ & 嗾 & 营总 & 产 & 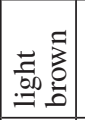 & 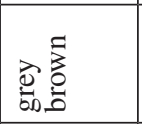 & 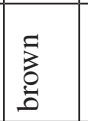 & 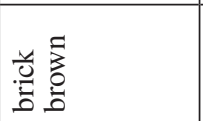 & 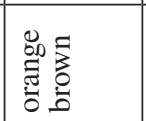 & 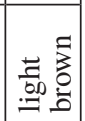 \\
\hline 党 & 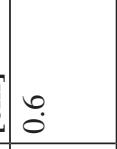 & $\tilde{3}$ & $\stackrel{0}{0}$ & $\hat{\circ}$ & $\because$ & ? & ?ִ & $\begin{array}{l}1 \\
0 \\
0 \\
0 \\
0\end{array}$ & $\hat{0}$ \\
\hline 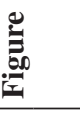 & $\ddot{\dot{t}}$ & $\begin{array}{l}\sim \\
\ddot{\forall} \\
\end{array}$ & $\ddot{\infty}$ & $\begin{array}{l}m \\
\ddot{\infty} \\
\end{array}$ & $\begin{array}{l}N \\
\ddot{\infty} \\
\end{array}$ & $\underset{\ddot{\infty}}{+}$ & $\begin{array}{l}n \\
\ddot{\infty}\end{array}$ & $\begin{array}{l}0 \\
\ddot{\infty}\end{array}$ & $\stackrel{\sim}{\ddot{\Xi}}$ \\
\hline 鸹 & 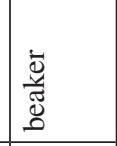 & 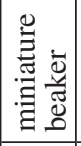 & 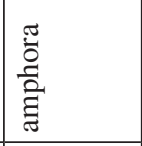 & 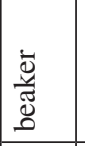 & 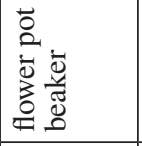 & 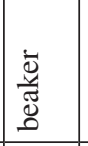 & 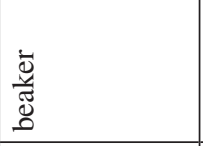 & 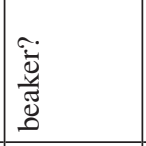 & 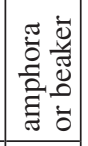 \\
\hline 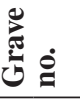 & $\cong$ & $\stackrel{\varrho}{I}$ & 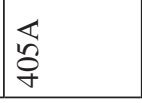 & \begin{tabular}{l}
\multirow{2}{*}{} \\
of \\
\end{tabular} & \begin{tabular}{|l}
$\mathbb{4}$ \\
o \\
\end{tabular} & 芯 & \begin{tabular}{l}
\multirow{2}{*}{} \\
$o$ \\
$q$
\end{tabular} & 芯 & 字 \\
\hline
\end{tabular}




\begin{tabular}{|c|c|c|c|c|c|c|c|}
\hline 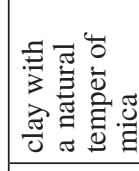 & & & & 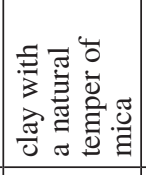 & & 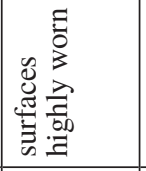 & \\
\hline 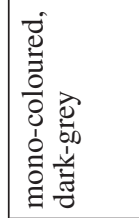 &  & 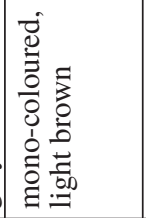 & 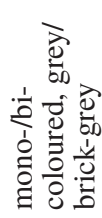 & & 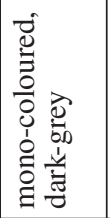 & 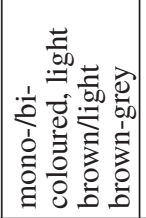 & 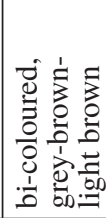 \\
\hline $\begin{array}{l} \\
\text { J } \\
\sim \\
\mathrm{v} \\
\end{array}$ & \begin{tabular}{|l|}
$\Xi$ \\
$\Xi$ \\
v \\
$v$ \\
\end{tabular} & 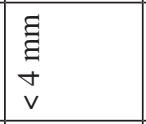 & $\begin{array}{l} \\
\vdots \\
m \\
\text { v } \\
\end{array}$ & \begin{tabular}{|l|}
$\Xi$ \\
$\Xi$ \\
$\sim$ \\
v \\
\end{tabular} & \begin{tabular}{|l|} 
\\
\\
g \\
v \\
v \\
\end{tabular} & \begin{tabular}{|l|} 
\\
$\Xi$ \\
ป \\
v \\
\end{tabular} & $\begin{array}{l}\Xi \\
\text { g } \\
\text { v } \\
\end{array}$ \\
\hline 䲶 & $\stackrel{\varrho}{\Xi}$ & 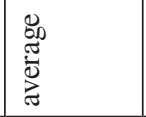 & 五 & $\stackrel{\varrho}{\Xi}$ & 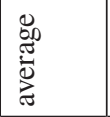 & $\stackrel{\varrho}{\Xi}$ & $\stackrel{\varrho}{\Xi}$ \\
\hline 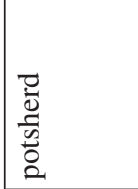 & 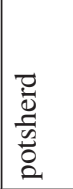 & 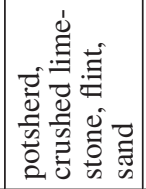 & 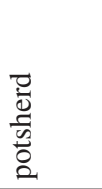 & 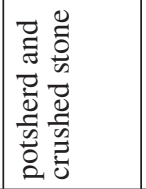 &  & 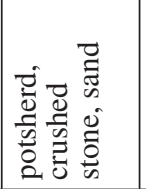 & 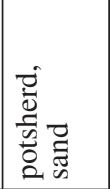 \\
\hline 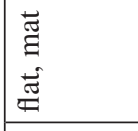 & 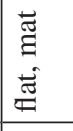 & 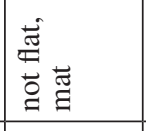 & 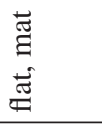 & 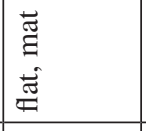 & 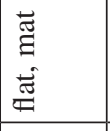 & 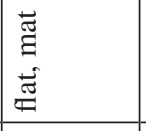 & 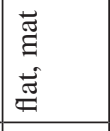 \\
\hline 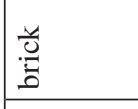 & 总 & 로유. & 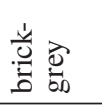 & 死 & 离言 & 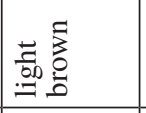 & 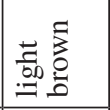 \\
\hline 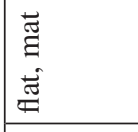 & 売 & 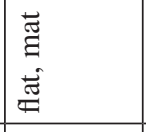 & 焉 & 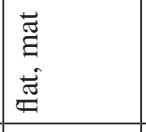 & 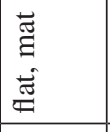 & 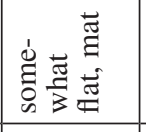 & 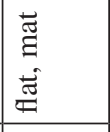 \\
\hline 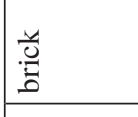 & 홍 & 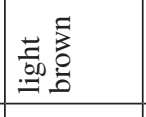 & 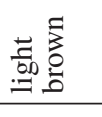 & ق & 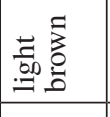 & 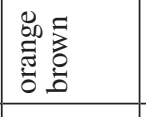 & 莺产 \\
\hline ? & $\begin{array}{l}0 \\
0 \\
1 \\
n \\
0 \\
0\end{array}$ & $\stackrel{0}{0}$ & : & $\tilde{n}$ & ñ & & $\because$ \\
\hline$\ddot{\ddot{\Xi}}$ & $\ddot{\theta}$ & 1 & 1 & & $\ddot{\ddot{n}}$ & $\ddot{\ddot{n}}$ & $\begin{array}{l}\sim \\
\ddot{n} \\
\ddot{u}\end{array}$ \\
\hline 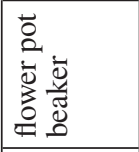 & 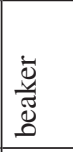 & a. & $\begin{array}{l}\frac{\pi}{0} \\
\overline{0} \\
\overline{\bar{z}} \\
\text { ज्ञ }\end{array}$ & $\therefore$ & 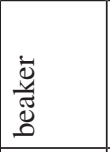 & 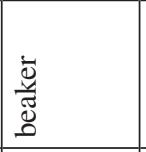 & 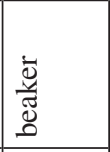 \\
\hline f & 字 & 杵 & ปั & $\stackrel{\mathcal{q}}{\mathcal{T}}$ & İ & 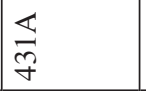 & 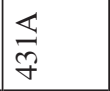 \\
\hline
\end{tabular}


the orientation of the graves towards each other nor the types of their construction point to the presence of barrows that could have been a source for the establishment of these concentrations.

It is rare to encounter the location of a CWC cemetery complex that is not used for settlement or funerary purposes in the previous phases of the Eneolithic (in particular by Funnel Beaker culture communities - as in the neighbouring sites 11 and 20 in Święte as well as 7 in Skołoszów). The graves under discussion here represent the oldest phase of using this area, distinguished on the basis of the presence of archaeological relics.

In this context, a dominant type of grave was the niche feature (six examples), though only in one case was it possible to document more details on its construction (grave 405A). The collected data shows that a characteristic trait of features in site 15 in Święte is the presence of clearly separated, long corridors that taper with a horizontal or somewhat diagonal orientation. Such an element of construction was confirmed in graves 405A, 407, 409 and 431A. The corridors were created horizontally from the bottom of a deep entrance shaft and led more or less horizontally to the grave niche. This is a type of niche grave rarely recorded in the Kraków-Sandomierz CWC group of the left bank River Vistula. In that region features dominated where between the entrance and the niche there existed a slanted, short corridor or a steep and high threshold. Analogous constructions however, at site 15 in Święte were also present at sites 5 and 6 in Szczytna [Hozer et al. 2017], 24 and 27 in Mirocin [Machnik et al. 2019] as well as at the neighbouring site 11 in Święte [Olszewski, Włodarczak 2018]. These were also documented at Sokal Ridge 5 .

The presence of features with entrance pits placed from the south of the grave niche is notable (features 405A, 407 and 431). This orientation also occurs at other sites from the Rzeszów Foothills in Szczytna [Hozer et al. 2017] and Mirocin [Machnik et al. 2019]. Placing the entrance from the south is often also encountered at the sites in Sokal Ridge [Machnik et al. 2009]. In the Kraków-Sandomierz group these however, appear rarely, characteristic first and foremost of graves located in the southern part of the barrow and in this way orientated in the main axis towards the centre of the mound. Perhaps worthy of note is the fact that the northsouth orientation of the main axis of the niche grave meant that the dead were placed accordingly west-east, just as in the older phase ('barrow') of the CWC. It therefore cannot be excluded that the arrangement with an entrance pit from the south is representative of an older tradition of CWC niche graves in Lesser Poland and then modified according to local traditions in some micro-regions.

At site 15 in Święte there were mainly single burials that were positioned with the preservation of the majority of prevailing principles in respect of funerary practices in all of south-eastern Poland. Thus the body was placed in a supine position with contracted lower limbs and head turned to the side, face turned towards the entrance (graves 173, 407, 409 and 431A). The internment from grave 427a proved

\footnotetext{
5 See Machnik et al. 2009 for a catalogue of these.
} 
to be exceptional - that of a boy aged 5 to 6 . The deceased was placed on their right side, head turned north and face turned west. An analysis of photographic documentation of the grave indicates that in all likelihood this was associated with the atypical orientation of the niche grave, with an entrance from the west. Such a positioning had not been recorded thus far in the Lesser Poland CWC. Neither has it been encountered in the local funerary rites of the Bell Beaker culture or Mierzanowice culture.

In grave 408, at the same level, the internment of two adult females was recorded. The remains of one (skeleton A) were scattered, disarticulated and incomplete, while the other, (B) lay articulated, on its left side (Fig. 16: A). The presence of interments and their different dates was also recorded in grave 43 from the neighbouring site 20 in Święte [Dobrakowska, Włodarczak 2018: Fig. 5: C] as well as at nearby sites in Mirocin (site 27, grave 360) [Machnik et al. 2019: 58-72] and Szczytna (site 5, grave 220) [Hozer et al. 2017: 19-28]. In all cases, disarticulated remains were highly incomplete. If one is to recognise that these were secondary burials disturbed in their initial placement of deposition (most likely during the burial of a subsequent individual), at a time of this disturbance a part of the remains had to be taken. Such a scenario should be recognised as being more probable than one that assumes initial internment of incomplete human remains. In the case of grave 408 it is also worthy to note the results of the analysis of stable strontium isotopes that point to the allochthonous origin of the individual buried during the secondary burial ceremony as well as the local provenance of the female placed in a contracted position on her side [Belka et al. 2018].

At the cemetery complex under study only one single burial was discovered of a male furnished in a characteristic means for CWC Lesser Poland funerary rites (grave 431A). Its burial goods contained two beakers (also fragments of subsequent, at least three, vessels were found), stone axe, two axes, bone chisel, blade tool as well as a flint flake. Analogous to other burials of males at sites in Święte, there were no elements of an archer's kit in these grave goods, usually present in the richest Lesser Poland inventories. In comparison to assemblages of numerous gifts found in some other graves from the Rzeszów Foothills, as well as western Lesser Poland, none of the above analysed assemblages presents in the category of richly furnished internments.

On account of the nature of ceramic furnishings the inventory from grave $405 \mathrm{~A}$, made up of six vessels, deserves note. In this feature the grave goods were deposited in one concentration, suggesting they were earmarked for a one-off, most likely single burial. Assemblages made up of more than four vessels are rare in CWC cemetery complexes from south-eastern Poland [Włodarczak 2006: 69, Table 21]. Exceptions to this prevailing norm therefore are of particular interest such as those in grave 28 from site 10 in Wilczyce, Sandomierz Upland [Włodarczak et al. 2015] or grave 1, barrow 1 at site 3 in Hubinek, Sokal Ridge [Machnik et al. 2009: 14, Fig. 5]. Burials recently discovered from the Rzeszów Foothills can also 
be counted among them such as those from site 6 in Szczytna (grave 4) [Hozer et al. 2017: 44, Fig. 24] as well as site 27 in Mirocin (grave 360) [Machnik et al. 2019: 58-73]. In particular, the internment from Hubinek is a good analogy for feature 405A, most likely a niche grave with an entrance from the south in which the furnishings were deposited and one concentration in the north of the niche.

Also in the case of the above the presence of only a few odd bones from an internment were confirmed. The objects from grave 405A can be associated with the furnishings of an adult; a numerous assemblage of vessels and a single small axe that are all characteristics of a female burial. The regular, knife blade insert or flint blank though, were recognised that time as determinants of male internments [Włodarczak 2006: 143-145].

Feature 426 was a small depressed pit, where no bones were found in the burial, only a small vessel (amphora?). Most likely it was meant as an offering ('tryzna'). These types of features are known from other Lesser Poland cemetery complexes with niche graves such as the neighbouring site 11 (feature 1284 and perhaps also feature 1149B) [Olszewski, Włodarczak 2018: 42, Fig. 31]. These are also present in kurgans and megalithic Middle Eneolithic tombs [Jarosz et al. 2009: 293]. Less probable would seem to be the burial purpose of the pit; internment of an infans I child (the bone remains would have at that time been completely decomposed). The number of such features in the case of the CWC documented a poorly identified funerary rite element may be underestimated - especially considering the rather frequent recording of the presence of vessels, bones or flint relics without an established context of stratigraphy (tumulus mound) or in pits of an unknown nature.

In the division of base types, the assemblage of vessels from site 15 in Siwięte appears to be rather homogenous. Beakers are in the decided majority (11), with only two amphorae (one, preserved as a small fragment) as well as one miniature vessel (two types of vessels from graves 405 and 407 were not determined because of their state of preservation, while in the case of feature 431A there is a lack of certainty as to the intentional nature of depositing into the grave three vessels represented as small fragments). Nonetheless, vessels clearly differentiated in respect to morphology and decoration are part of the beaker assemblage, presenting at the same time genetic differences.

The majority of beakers is characteristic for materials from Subcarpathia niche graves of the CWC. Among these are large S-profile vessels, type IV according to Machnik [1966] and Włodarczak [2006], also embellished with cord imprints (grave 173: Fig. 4: 1) as well as non-decorative ones (grave 431A: Fig. 25: 2). In the collection they were also the most numerous in this area, medium sized S-profile forms of various proportions (graves 405A and 407: Fig. 10: 5-6; 16: 1). Further, two small unipartite beakers were identified (graves 405A and 407: Fig. 8: 2; 14: 1), two broad-mouth vessels (graves 405A and 431A: Fig. 9: 4; 25: 1) as well as a small open 'hourglass' beaker (grave 427: Fig. 23: 1). 
Small unipartite beakers ('pot plant') in both cases were part of a highly differentiated ceramic inventory. These vessels represent sub-types really encountered in furnishings from south-eastern Poland, where straight-walled forms were characteristic, with vertical sides (sub-type VIB) or 'V-shaped' (sub-type VIA). The beaker from grave 405A (Fig. 8: 2) is a barrel form with arched walls - sub-type VIE [Włodarczak 2006: 15], only very occasionally present in features of the Kraków-Sandomierz CWC group, inventories from Sokal Ridge [Machnik et al. 2009: 53, Fig. 38: 2] as well as the Upper Dniester [Sulimirski 1968: Pl. 8: 4]. The odd few analogous beakers come from cemetery complexes of the Middle Dnieper culture [Artemenko 1967: 49, Fig. 35. 3].

The small vessel from grave 407 though, is unique - with thin, lightly profiled walls and an outlined bottom (Fig. 14: 1). Only in general terms is it possible to consider this part of the group of small, undecorated vessels that are rather occasionally recorded in the inventories of the Lesser Poland CWC (most often as an accompanying piece for a large vessel), while somewhat more often - in the interments of various traditions in the North Pontic area - from the Eneolithic to the Middle Bronze Age (Ukrainian - mugs; Ivanova 2013: Figs. 3.40-3.41). Analogous vessels, both as an additional component of a ceramic inventory, are present in the funerary assemblages from the western CWC regions, including those from the Czech Republic as well as Germany (German: Dose; Czech: dósa, dózovita nádobka), demonstrating everywhere a large differentiation in respect to shape [Buchvaldek 1986: obr. 13: J1-J5].

Broad-mouth forms - from graves 405A (Fig. 9: 4) and 431A (Fig. 25: 1) are rarely encountered in the grave inventories of the Lesser Poland CWC. Their difference was marked in an attempt to create a taxonomy by establishing 'type III' [Machnik 1966: 27; Włodarczak 2006: 13-14]. Vessels such as these at times take on the proportions of a vase and are rather differentiated in respect to size and proportion. Thus there are forms with high or short necks, mainly S-shaped, rarely markedly profiled. Some of these have been classified to a separate category of 'amphora-like vessels of the Brzezinki type' [Machnik 1966: 36-37]. Of particular note is the clear stylistic similarity of these forms with the pot-like vessels that constitute the basic element of ceramic furnishings in the late Yamnaya culture and first and foremost in the early Catacomb culture [Toschev 2013: 75, Fig. 2; Ivanova, Toschev 2015: 383, Fig. 30: 1]. Bearing in mind the proximity of this culture circle, various types of broad-mouth vessels appear in the eastern peripheries of the CWC circle - in the upper Dniester basin (Komarów and Lotatniki) [Sulimirski 1968: Plate 6: 2, 3].

In terms of ornamentation and original form the 'beaker' from grave 431 A (Fig. 25: 1) stands out. It is in the form of a vase with a short, somewhat V-shaped neck, embellished with a rather elaborated arrangement of incisions and imprints. In similar fashion the beakers of type IIIb are embellished according to Machnik [1966: 27], such as those from Dratów [Chotyński 1908: 65], Mokrelipie [So- 
chacki 1964: 176, Fig. 4a], Sługocin [Bienia et al. 2016: 262, Fig. 5: 2], Lublin-Sławinek [Jarosz, Rejniewicz 2016: 340, Fig. 10: 1], or the environs of Zamość [Nosek 1957: Table XX: 6]. It is therefore a characteristic style first and foremost for the Lublin region that occurs also in the Sandomierz Upland (Kichary Nowe, grave 26). Its origin is associated with the ornamentation of Globular Amphora culture [Jarosz 2016: 528], or that of the Middle Dnieper culture [Machnik et al. 2001: 395-396. Fig. 4]. In comparison to these two cultural circles, the means of vessel ornamentation in grave 431 A (herringbone together with puncturing) finds however, even better analogies in Middle Dnieper ceramic ware [Artemenko 1967: 75, Fig. 44].

In addition, one of the beakers from grave 405A points to the above 'eastern' stylistic tendency (Fig. 9: 4). This vessel belongs to the group of relics embellished with mini rows of uneven incisions - similar to the beaker from the barrow I in Brzezinki [Machnik 1966: Table XIX: 2a]. This type of ornamentation is characteristic for CWC vessels from the eastern Lesser Poland, where it is also present on beakers as well as amphorae. In this context, the above was identified by Machnik as part of a group of traits pointing to the Middle Dnieper culture style [Machnik et al. 2001: 395, Fig. 4].

An important fact in this context is the co-occurrence of vessels with foreign traits ('eastern') in respect to ceramic relics with local characteristics as illustrated by the inventories of graves $405 \mathrm{~A}$ and $431 \mathrm{~A}$ from site 15 as well as grave $756 \mathrm{~A}$, site 11 in Święte [Olszewski, Włodarczak 2018: 14, Fig. 5: 1]. This is even more evident in the case of grave 54 from the nearby site 24 in Mirocin, where a beaker typical of Middle Dnieper culture was discovered together with vessels characteristic of the local CWC [Machnik 2014: 99, Fig. 6; Machnik et al. 2019: 69, Fig. 38: 5]. Thus far, an exception in this respect is the assemblage of three beakers from Młodów-Zakącie in Roztocze, where all the vessels have a 'foreign' form (Middle Dnieper) [Machnik, Pilch 1997].

The vessel from grave 427 (Fig. 23: 1) is considered to belong to the group of small hourglass beakers demonstrating traits of Middle Dnieper culture ceramic ware [Machnik, Pilch 1997; Machnik et al. 2001; 2009]. It is not embellished in an elaborate fashion that is characteristic for this type of vessel, but only with horizontal cord imprints. It therefore belongs to the group of small beakers associated with the Middle Dnieper culture - just as the vessels from the nearby site in Siedliska [Demetrykiewicz 1898: 77, Fig. 1].

Non-ceramic inventories from site 15 in Święte are relatively poor. Only in features $405 \mathrm{~A}$ and $431 \mathrm{~A}$ was the presence of a greater number of objects confirmed. All the relics belong to the category of objects characteristic for Lesser Poland CWC grave inventories. The most numerous group was that of flint goods discovered in four graves. In two features, goods made of rock (not flint) were an element of furnishings. In addition, two other graves revealed the odd few bone tools. 
Grave $431 \mathrm{~A}$ revealed a stone axe where a male aged 40 to 50 was interred. The former has a regular form, rhomboid in the main profile with only a slightly asymmetrical blade. In terms of typology accenting the development of such from type A forms, this axe can be placed in a group associated with Old Corded specimens and may be considered belonging to type I according to Machnik [1966: 42], type C according to Włodarczak [2006: 33] as well as sub-type ID of Libera and Sobieraj [2016: 429-432]. The majority of such specimens constitute scattered finds. Worthy of note is the presence of similar axes in two grave assemblages: feature 5 from Książnice Wielkie, Lesser Poland Upland as well as in the barrow from Morawsko, Rzeszów Foothills [Machnik 1995: 7, Fig. 3b]. These are inventories characteristic for the older development stages of the CWC.

There is a lack of data however, in respect to the construction of graves and their stratigraphy. The feature from Morawsko was interpreted as belonging to a barrow [Machnik 1995], although the nature of furnishings rather indicates secondary interments dug into the mound fill. On account of the characteristics of the beaker from the above, the chronology would appear to be close to the period of cemetery complexes with niche graves in the Rzeszów Foothills as well as San Valley. The traits of the axe from grave 431A in Święte, analogous to the Early Corded stage, rather suggest its older position in the context of the younger stage of the CWC the period of niche grave cemetery complexes. This constitutes a confirmation of the carbon dating below for this feature.

Moreover, the presence of axes with 'old' traits in the niche graves was also attested to in features from the Rzeszów Foothills at site 5 in Szczytna (grave 220) [Hozer et al. 2017: 27, Fig. 13: 7] as well as site 27 in Mirocin (grave 360) [Machnik et al. 2019: 69, Fig. 38: 18]. The case of Szczytna is particularly intriguing, where the element of a late, radiocarbon dated assemblage (about 2400-2300 BC) was typologically a very early form of axe, type I. One explanation for such a situation is a diachronic cultural model that implies a very long, multi-generational exploitation of symbolic and prestigious objects.

The axes (three examples) come from two features (405A and 431A). Two of these broaden the base of axes made out of non-flint materials characteristic for the Lesser Poland Subcarpathian region that in small number were also exported to neighbouring regions (Lesser Poland Upland, Roztocze and Sokal Ridge). The relic from grave 405A is a small form made out of siltstone - just as the tools from neighbouring sites 11 and 20 in Święte. The specimen from grave 431A, because of its material, is unique - made out of amphibolite. This kind of rock, broadly exploited for the production of axes in the early phases of the Neolithic by Danube culture circle communities, has not been thus far noted in core tool production of the Lesser Poland CWC. It is similar to older Neolithic tools through the oval nature of side walls and a lack of clear side edges. This is not however, a trait that would determine the fact of re-utilisation of Early Neolithic forms. Importantly, some other stone axes from the Subcarpathian region have similar typological traits. 
In grave 431A a quadrifacial axe of Volhynia flint was also found. It belongs to the group of flat forms with a regular, formed surfaces, polished at the blade. Here, it shows a reduction of side surface width, which enabled a flat and thin form, one analogous to bifacial axes present in the CWC assemblages from neighbouring cemetery complexes (among others from Szczytna, Mirocin as well as sites 11 and 20 in Święte). Flat rectangular axes of the PS type [Budziszewski, Włodarczak 2011: 58, Abb. 4] are a characteristic element of Lesser Poland grave inventories. In the Subcarpathia region, as in the case of feature 431A from Święte, they are typified by appearing together with the thicker axes made out of local non-flint rock.

Only in three graves were flint flake and blade tools discovered. In this context, short flint scrapers and endscrapers such as those discovered in grave 408 (Fig. 16: 2,3) can be said to be a rare element of furnishings in Lesser Poland CWC graves. An assemblage of two such tools has only been found thus far in grave 33 from Żerniki Górne [Kempisty 1978: 44, Fig. 49: 4, 5]. Flint scrapers and endscrapers it should be noted, are most often found in female interments such as in grave 408 .

A typical element of grave furnishings (first and foremost male) is the knife blade insert such as the specimen from grave 405A (Fig. 11: 7) as well as the dagger blade point (form in grave 431A - Fig. 27: 6). Both these types of tools were made out of selected types of material (In the western Lesser Poland and Lublin Upland - from chocolate flint, in Eastern Lesser Poland, in the Subcarpathia region - Volhynia flint). This particular choice of material concerns foremost grave inventories. Settlement materials though (that continue to be few), point to a wider range of materials used in this context.

Assemblages of flint flakes - just as that of relics from grave 405A - are a typical element of grave furnishings for adult males, constituting an integral part of the richest Lesser Poland inventories as an element of the flint worker's kit together with assemblages of bone and antler tools (grave 4 from Szczytna, grave 3 from Koniusza or grave 1(2), Żuków) [Hozer et al. 2017; Tunia 1979; Marciniak 1960]. Rare are however, male burials analogous to grave 405A, Święte, were we have a poorer set of grave goods (Żerniki Górne, graves 66 and 141) [Kempisty, Włodarczak 2000: 37, Fig. 22; 103-104, Fig. 67-68].

Two bone relics - an awl as well as a fragment of a goat or sheep metacarpal - come from grave 408 (internment of two females). The latter relic is perhaps a fragment or awl blank, as suggested by the type of bone used. Awls are the only type of bone tool that occurs in female graves. The element typical for male burials however, is the bone chisel from grave $431 \mathrm{~A}$ - a type of tool consistently made out of a cattle radial bone. The relic from the above-mentioned feature belongs to the clearly dominant group of massive, broad-blade forms [Włodarczak 2006: 36].

In the light of the above discussion for typological relics in grave inventories and a review of general rite traits a rather clear conclusion can be drawn in respect to the culture and chronology of graves from site 15 in Święte. These finds represent in all likelihood one chronological horizon that links with the younger 
phase of the CWC in south-eastern Poland - one of the domination of interments in niche graves. The construction variants of these features are different from that of the Kraków-Sandomierz CWC group, but also differ from features of the Złota culture type, dated to the older phase, Final Eneolithic (most often 2800-2600 BC). The means of burial placement and type of furnishings are the same as in other regions of Lesser Poland (Lesser Poland Upland, Lublin Upland, Roztocze or Sokal Ridge).

First and foremost the similarity to materials is visible from neighbouring cemetery complexes in Święte (sites 11 and 20), Skołoszów (site 7), Szczytna (sites 5 and 6) as well as Mirocin (sites 24 and 27). The majority of grave finds of the CWC from Lesser Poland belong to this chronological horizon. Pit burials under barrow are older, while the younger ones are the odd few assemblages with mixed traits containing relics characteristic for the Early Bronze Age. Nonetheless, although the decided majority of grave finds belong to the above chronology, it is difficult in the context of this phase to make further subdivisions of period - reason being, the relatively brief length of this phase established by means of absolute chronology.

The series of six radiocarbon datings verify the record of relative chronology [Włodarczak 2018: Table 1]. These results stand out for their contents and at the same time indicate the younger phase of the CWC from about the middle of the third millennium BC to about $2400 / 2350$ BC. The graves at nearby cemetery complexes at sites 11 and 20 in Święte [Włodarczak 2018] and those at site 7 in Skołoszów [Rybicka et al. 2017: 128, Table 2] are of the same period. The ${ }^{14} \mathrm{C}$ from the cemetery complex under discussion can be divided into two groups. The somewhat older category - about 2575-2470 BC - is indicated for graves 409 and 431A. The remaining four datings (for graves 173, 407, 408A and 427) relate to the period about 2480-2350 BC. Recognising that all the graves belong to the one chronological phase, the period of 2525-2382 BC is obtained for the cemetery complexes in site 15 in Święte. In the context of chronometric research this is the middle and late part of the younger phase of the Lesser Poland CWC, where the majority of niche graves analysed is dated.

\section{CONCLUSION}

The materials from CWC cemetery complexes at site 15 in Święte constitute one of the richest assemblages of sources for research on Final Eneolithic funerary rites in the Subcarpathia region. The poor state of preservation in respect to some of the features alas, creates serious problems of interpretation as far as defining construction type and function of parts of the features. What is indisputable is the 
fact that all of these finds are associated with funerary rites. The better preserved graves, in regard to their niche construction can be linked to features from neighbouring sites on the Lower San Valley as well as in the Rzeszów Foothills. The traits of grave goods inventory allowed to number the above discussed cemetery complex among the vast ceremonial funerary ones located on the series of loess hills beyond the San Valley, including the cemetery complexes of sites 11 and 20 in Święte as well as site 7 in Skołoszów.

In this region however, there is a lack of materials that would link with the older CWC phase. The Final Eneolithic cemetery complexes arose by the megalithic long barrows of the Funnel Beaker culture or on a territory previously not designated for funerary purposes. Most likely this was associated with locating the barrow of the older CWC phase with the northernmost region located deep in the upland [similar context to western Lesser Poland: Kruk 1973: 107]. In the younger phase of the Final Eneolithic (about the middle of the third millennium BC) these conditions in part underwent change, establishing cemetery complexes also in lower but still marked areas of the surrounding region (first and foremost on the peripheries of large valleys).

All the features in this context in site 15 in Święte are dated to the period approximately $2500-2400 \mathrm{BC}$. Here, the presence of relics pointing to relations with areas to the east of Lesser Poland is of particular note. The fact that the aforesaid was linked to another, younger wave of migration from eastern areas is further attested to by the above-mentioned research results of strontium stable isotope analysis [Belka et al. 2018]. 


\section{REFERENCES}

Artemenko I.I.

1967 Plemena verkhnego i srednego Podneproviya w epokhu bronzy. Moskva.

Belka Z., Dopieralska J., Szczepanek A., Jarosz P.

2018 Human mobility in the Final Eneolithic population of Święte, Jarosław District, south-eastern Poland: evidence from strontium isotope data. Baltic-Pontic Studies 23: 246-258.

Bienia M., Budziszewski J., Niedźwiedź E., Niedźwiedź J., Włodarczak P.

2016 Kurhan kultury ceramiki sznurowej na stanowisku 5 w Sługocinie, pow. lubelski. In: P. Jarosz, J. Libera, P. Włodarczak (Eds) Schyłek neolitu na Wyżynie Lubelskiej, 257-286. Kraków.

Buchvaldek M.

1986 Kultura se šñurovou keramikou ve střední Evropě. Praehistorica 12. Praha.

Budziszewski J., Włodarczak P.

2011 Die schnurkeramischen Beile aus den kleinpolnischen Gräbern. In: H.-J. Beier, R. Einicke, E. Biermann (Eds) Dechsel, Axt, Beil \& Co Werkzeug, Waffe, Kultgegenstand? Aktuelles aus der Neolithforschung. Varia Archaeologica 7. Beiträge zur Ur- und Frühgeschichte Mitteluropas 63, 55-64. Langenweissbach.

Chotyński A.

1908 Zabytki przedhistoryczne nad rzeczką Chodlem. Światowit 8: 64-65.

Demetrykiewicz W.

1898 Neolityczne groby szkieletów tak zw. siedzących (Hockergräber) w Przemyskiem i Krakowskiem. Materiały Antropologiczno-Archeologiczne i Etnograficzne 3: 76-92.

Dobrakowska T., Włodarczak P.

2018 Święte 20: graves of the Corded Ware culture. Baltic-Pontic Studies 23: 140-162.

Hozer M., Machnik J., Bajda-Wesołowska A.

2017 Groby kultury ceramiki sznurowej i domniemane kultury mierzanowickiej w Szczytnej, pow. Jarosław - źródła, analizy, wnioski. In P. Jarosz, J. Machnik (Eds) Nekropolie ludności kultury ceramiki sznurowej z III tysiąclecia przed Chr. w Szczytnej na Wysoczyźnie Kańczuckiej. Via Archaeologica Ressoviensia 12, 7-130. Rzeszów. 
Ivanova S.V.

2013 Kulturno-istoricheske kontakty naseleniya Severo-Zapadnogo Prichernomoria v rannem bronzovom veke: Zapad-Vostok. Stratum plus 2(2013): $158-248$.

Ivanova S.V., Toschev G.N.

2015 The Middle-Dniester cultural contact area of early metal age societies. The frontier of Pontic and Baltic drainage basins in the 4th/3rd-2nd millennium BC. Baltic-Pontic Studies 20: 336-405.

Jarosz P.

2016 Kultura ceramiki sznurowej na Wyżynie Lubelskiej i terenach przyległych. In: P. Jarosz, J. Libera, P. Włodarczak (Eds.) Schyłek neolitu na Wyżynie Lubelskiej, 209-536. Kraków.

Jarosz P., Rejniewicz Ł.

2016 Schyłkowoneolityczne cmentarzysko kultury ceramiki sznurowej na stanowisku 3 w Lublinie-Sławinku. In: P. Jarosz, J. Libera, P. Włodarczak (Eds) Schyłek neolitu na Wyżynie Lubelskiej, 329-348. Kraków.

Jarosz P., Tunia K., Włodarczak P.

2009 Burial mound no. 2 in Malżyce, the district of Kazimierza Wielka. Sprawozdania Archeologiczne 61: 175-231.

Kempisty A.

1978 Schytek neolitu i początek epoki brązu na Wyżynie Małopolskiej w świetle badań nad kopcami. Kraków.

Kempisty A., Włodarczak P.

2000 Cemetery of the Corded Ware culture in Żerniki Górne. Światowit Supplement Series P: Prehistory and Middle Ages 5. Warsaw.

Kruk J.

1973 Studia osadnicze nad neolitem wyżyn lessowych. Wrocław-Warszawa-Kraków-Gdańsk.

Libera J., Sobieraj J.

2016 Topory kamienne jako identyfikatory kultury ceramiki sznurowej w środkowej i północnej części Lubelszczyzny. In: P. Jarosz, J. Libera, P. Włodarczak (Eds) Schyłek neolitu na Wyżynie Lubelskiej, 411-454. Kraków.

Machnik J.

1966 Studia nad kulturq ceramiki sznurowej w Małopolsce. Wrocław-Warszawa-Kraków. 
1995 Zapomniany kurhan kultury ceramiki sznurowej w Morawsku koło Jarosławia. Rocznik Przemyski 31, 3-22.

2014 Transfer of ideas and cultural (taxonomic) traits between the Vistula and Dnieper in the late Neolithic. Archaeological evidence on Subcarpathian plateaus. Baltic-Pontic Studies 19: 87-106.

Machnik J., Bagińska J., Koman W.

2001 Nowa, synkretyczna grupa kultury ceramiki sznurowej w Polsce środkowo-wschodniej. In: B. Ginter, B. Drobniewicz, B. Kazior, M. Nowak, M. Połtowicz (Eds) Ksiega jubileuszowa dedykowana Profesorowi Januszowi K. Kozłowskiemu $w$ czterdziestolecie pracy naukowej $w$ Uniwersytecie Jagiellońskim, 391-400. Kraków.

2009 Neolityczne kurhanyna Grzędzie Sokalskiej w świetle badan archeologicznych w latach 1988-2006. Z aneksami Jerzego Libery i Lucjana Gazdy. Kraków.

Machnik J., Jarosz P., Mazurek M.

2019 Groby ludności kultury ceramiki sznurowej w Mirocinie, pow. Przeworsk. In: P. Jarosz, J. Machnik, A. Szczepanek (Eds) Nekropolie ludności kultury ceramiki sznurowej z III tysiaclecia przed Chr. w Mirocinie na Wysoczyźnie Kańczuckiej. Via Archaeologica Ressoviensia 15, 7-134. Rzeszów.

Machnik J., Pilch A.

1997 Zaskakujące odkrycie zabytków kultury środkowodnieprzańskiej w Młodowie-Zakąciu koło Lubaczowa w woj. przemyskim. Sprawozdania Archeologiczne 49: 143-170.

Marciniak J.

1960 Materiały neolityczne z Żukowa, pow. Sandomierz. Materiały Archeologiczne 2: 43-55.

Nosek S.

1957 Materiały do badań nad historia starożytna i wczesnośredniowiecznq międzyrzecza Wisty i Bugu. Annales Universitatis Mariae Curie-Skłodowska F6. Lublin-Kraków.

Olszewski A., Włodarczak P.

2018 Święte 11: cemetery of the Corded Ware culture. Baltic-Pontic Studies 23: 7-68.

Reder J.

2013 Analiza geologiczno-geomorfologiczno-glebowa stanowiska Święte 15, woj. podkarpackie. In: P. Janczewski, A. Falis, J. Kraus (Eds) Święte 
15/127/106-84 AZP, stanowisko w gminie Radymno, woj. podkarpackie tom II analizy. Wrocław [manuscript].

Rybicka M., Głowacz M., Król D.

2017 Datowania radiowęglowe wielokulturowego cmentarzyska ze Skołoszowa, stanowisko 7, pow. jarosławski, woj. podkarpackie. In: M. Rybicka (Ed.) Wielokulturowe cmentarzysko w Skotoszowie, stanowisko 7 pow. jarosławski w kontekście osadnictwa z neolitu $i$ wczesnej epoki brązu we wschodniej części Podgórza Rzeszowskiego, 113-142. Rzeszów.

Sochacki Z.

1966 Grób z wczesnego okresu epoki brązu ze wsi Mokrelipie, pow. Zamość. Wiadomości Archeologiczne 31(2-3): 174-178.

Sulimirski T.

1968 Corded Ware and Globular Amphorae north-east of the Carpathians. London.

Toschev G.N.

2013 In the west of the Catacomb area. Baltic-Pontic Studies 18: 72-85.

Tunia K.

1979 Cmentarzysko kultury ceramiki sznurowej w Koniuszy, woj. Kraków. Sprawozdania Archeologiczne 31: 47-75.

Włodarczak P.

2006 Kultura ceramiki sznurowej na Wyżynie Małopolskiej. Kraków.

2018 Chronometry of the Final Eneolithic cemeteries at Swięte, Jarosław District, from the perspective of cultural relations among Lesser Poland, Podolia and the north-western Black Sea region. Baltic-Pontic Studies 23: 178-212.

Włodarczak P., Boroń T., Kurzawska A., Osypińska M., Szczepanek A., Winiarska-Kabacińska M.

2016 Grób kultury ceramiki sznurowej ze stanowiska 10 w Wilczycach, pow. sandomierski. Przeglad Archeologiczny 64: 29-57. 